\title{
Rampant tooth loss across 200 million years of frog evolution
}

Daniel J. Paluh ${ }^{1,2}$, Karina Riddell ${ }^{1}$, Catherine M. Early ${ }^{1,3}$, Maggie M. Hantak ${ }^{1}$, Gregory F.M.

5 Jongsma ${ }^{1,2}$, Rachel M. Keeffe ${ }^{1,2}$, Fernanda Magalhães Silva ${ }^{1,4}$, Stuart V. Nielsen ${ }^{1}$, María Camila Vallejo-Pareja ${ }^{1,2}$, Edward L. Stanley ${ }^{1}$, David C. Blackburn ${ }^{1}$

$8{ }^{1}$ Department of Natural History, Florida Museum of Natural History, University of Florida,

9 Gainesville, Florida USA 32611

$10 \quad{ }^{2}$ Department of Biology, University of Florida, Gainesville, Florida USA 32611

11 B3iology Department, Science Museum of Minnesota, Saint Paul, Minnesota USA 55102

12 Programa de Pós Graduação em Zoologia, Universidade Federal do Pará/Museu Paraense

13 Emilio Goeldi, Belém, Pará Brazil

14

15 *Corresponding author: Daniel J. Paluh, dpaluh@ufl.edu, +1 814-602-3764

16

17 Key words: Anura; teeth; edentulism; toothlessness; trait lability; comparative methods 


\section{Abstract}

19 Teeth have been broadly maintained across most clades of vertebrates but have been lost

20 completely at least once in actinopterygian fishes and several times in amniotes. Using

21 phenotypic data collected from over 500 genera via micro-computed tomography, we provide

22 the first rigorous assessment of the evolutionary history of dentition across all major lineages of

23 amphibians. We demonstrate that dentition is invariably present in caecilians and salamanders,

24 but teeth have been lost completely more than 20 times in frogs, a much higher occurrence of

25 edentulism than in any other vertebrate group. The repeated loss of teeth in anurans is

26 associated with a specialized diet of small invertebrate prey as well as shortening of the lower

27 jaw, but it is not correlated with a reduction in body size. Frogs provide an unparalleled

28 opportunity for investigating the molecular and developmental mechanisms of convergent tooth

29 loss on a large phylogenetic scale. 


\section{Introduction}

31 The evolution of teeth is considered a key innovation that promoted the radiation of jawed

32 vertebrates, facilitating the transition from a passive to active predatory lifestyle (Gans and

33 Northcutt 1983). Teeth are complex mineralized tissues that originated in stem gnathostomes

34 more than 400 million years ago (Rücklin et al. 2012) and have been broadly maintained across

35 living chondrichthyans, actinopterygians, and sarcopterygians due to the critical role these

36 structures play in the acquisition and processing of food. The shape, size, location, and number

37 of teeth differ widely across vertebrates, especially in response to broad variation in food type.

38 Although dentition is generally conserved across vertebrates, teeth have been lost completely

39 several times, resulting in toothlessness or edentulism, including in three extant clades of

40 mammals (baleen whales, anteaters, and pangolins), turtles, and birds (Davit-Béal et al. 2009).

41 Teeth are likely lost following the evolution of a secondary feeding tool that improves the

42 efficiency of food intake (e.g., beak, baleen, specialized tongue), leading to relaxed functional

43 constraints on dentition (Davit-Béal et al. 2009). In contrast to other tetrapods, the evolution and

44 diversity of teeth in amphibians has been poorly studied, despite long recognition that frogs-

45 one of the most diverse vertebrate orders with more than 7,000 species-possess variation in

46 the presence or absence of teeth.

47 All living salamanders and caecilians are assumed to have teeth on the upper jaw, lower

48 jaw, and palate (Duellman and Trueb 1986), but nearly all frogs lack dentition on the lower jaw

49 and variably possess teeth on the upper jaw and palate. Recent work suggests that dentition on

50 the lower jaw was lost in the ancestor of frogs more than 200 million years ago and was

51 subsequently regained in a single species (Gastrotheca guentheri; Boulenger 1882) during the

52 Miocene (Wiens 2011). The presence or absence of dentition has also been considered an

53 important taxonomic character in frogs; for example, a subclass was once proposed that

54 included all toothless species (Bufoniformia; Cope 1867). Our understanding of the anuran tree

55 of life has fundamentally changed with the development of molecular phylogenetics (Duellman 
and Trueb 1986, Feng et al. 2017; Hime et al. 2020), but there has been no attempt to estimate

57 the frequency of tooth loss across frog diversity or evaluate the factors that may be correlated

58 with edentulism. Most frogs are generalist, gape-limited predators that capture prey using

59 tongue propulsion (Regal and Gans 1976), reducing the importance of teeth in prey capture.

60 Tooth loss is hypothesized to occur in frogs that specialize on eating small prey (microphagy),

61 such as ants and termites (Das and Coe 1994, Parmelee 1999, Narvaez and Ron 2013). This

62 may lead to relaxed functional constraints on energetically expensive teeth. Microphagous frogs

63 are known to have shortened jaws and altered feeding cycles (Emerson 1985), modified

64 tongues (Trueb and Gans 1983), and some have the ability to sequester dietary alkaloids from

65 their prey, rendering them toxic (Caldwell 1996, Vences et al. 1998). Alternately, teeth may be

66 reduced or lost as a byproduct of miniaturization or truncated development (paedomorphosis;

67 Davies 1989, Hanken and Wake 1993, Smirnov and Vasil'eva 1995) because the initiation of

68 odontogenesis occurs ontogenetically late in frogs (during or after metamorphosis) compared to

69 other vertebrates.

Using the most recent species-rich phylogeny of extant amphibian species (Jetz and

71 Pyron 2018) and our extensive taxonomic sampling via high-resolution X-ray micro-computed

72 tomography of over 500 of the 561 currently recognized amphibian genera (AmphibiaWeb

73 2021), we 1) evaluated the phylogenetic distribution of teeth and reconstructed the evolutionary

74 history of dentition across all major lineages of amphibians and 2) tested whether dietary

75 specialization, relative jaw length, and body size are correlated with the loss of teeth in frogs.

76 Our results demonstrate that the presence and location of teeth are highly conserved in

77 salamanders and caecilians, but labile in frogs. We found that teeth have been repeatedly lost in

78 frogs and at a much higher frequency than in any other vertebrate group. The evolution of

79 edentulism in anurans is correlated with a microphagous diet and shortening of the lower jaw

80 but not with a reduction in body size over evolutionary time. Six reversals, from edentulous to

81 toothed jaws, were inferred in frogs. 


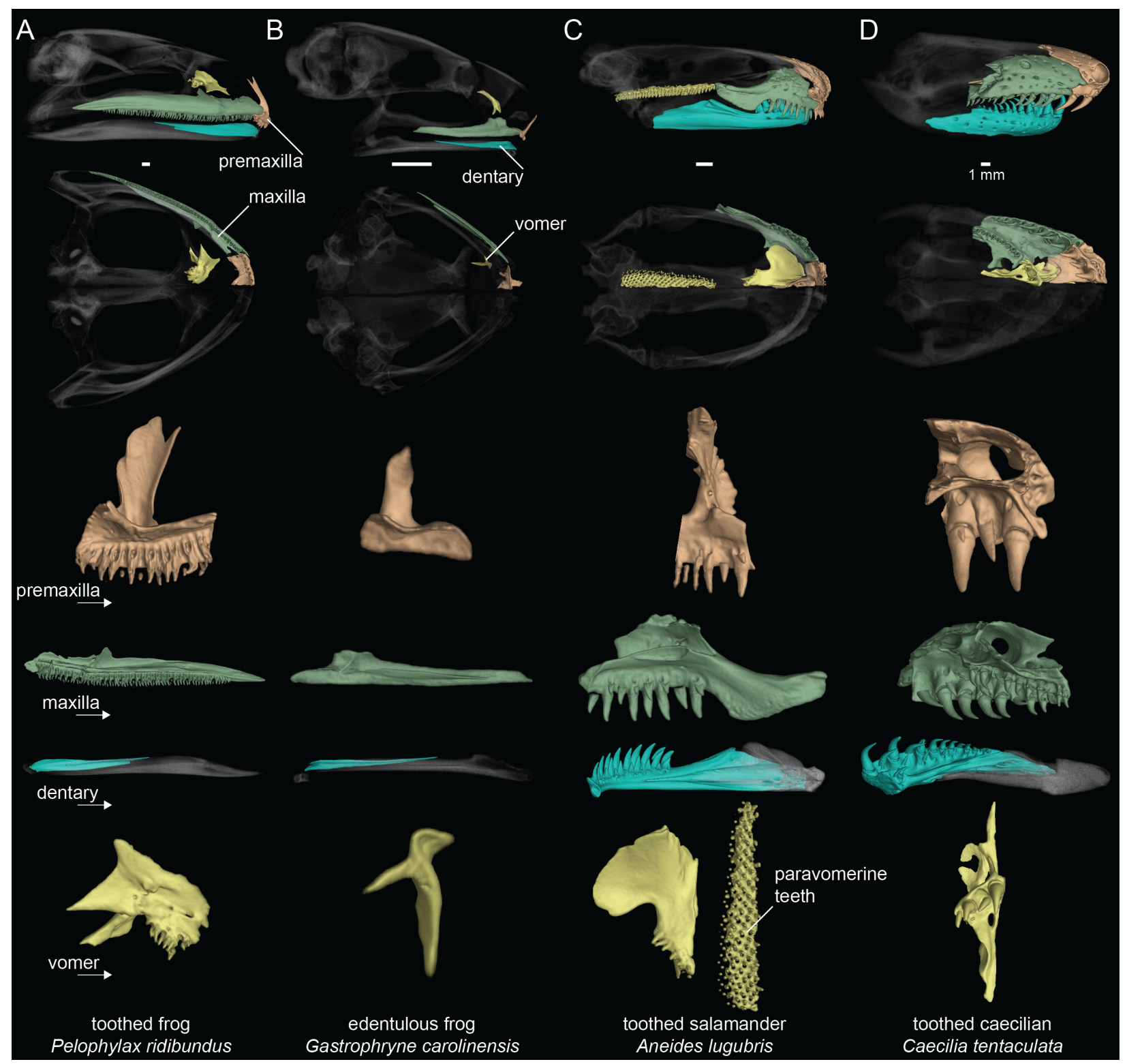

Figure 1. Dental diversity of amphibians. A. Toothed frog, Pelophylax ridibundus (CAS:Herp:217695), B. edentulous frog, Gastrophryne carolinensis (UF:Herp:110645), C. toothed salamander, Aneides lugubris (MVZ:Herp:249828), D. toothed caecilian, Caecilia tentaculata (KU:Kuh:175441). Skulls in lateral and ventral views: dentigerous cranial elements are colored and the remainder of the skull is semi-transparent. Isolated premaxilla (orange), maxilla (green), and dentary (blue) in lingual views. Isolated vomer (yellow) in ventral views. Teeth are present on all colored elements except the dentary in $P$. ridibundus and those of $G$. carolinensis. Scale bars $=1$ $\mathrm{mm}$. 


\section{Results}

\section{Distribution of teeth in amphibians}

85 We recorded the presence or absence of teeth on each dentigerous bone of the lower jaw,

86 upper jaw, and palate for 524 amphibian species (Fig. 1; Dataset S1). Taxa were coded as

87 "toothed" if teeth were observed on any cranial element and "edentulous" if teeth were entirely

88 absent. Our survey of amphibian dentition across the majority of extant genera confirmed that

89 all salamanders and caecilians retain teeth, while 134 of the 429 frog species examined are

90 entirely edentulous (Dataset S1). All anuran species lack dentary teeth with the exception of

91 Gastrotheca guentheri. Maxillary and premaxillary teeth of the upper jaw co-occur in all frog

92 species (Fig. 1A, 1B), being present in 292 taxa and absent in 136 species. The vomerine teeth

93 on the palate are the most variable in frogs, being present in 202 species and absent in 226.

94 Many anurans have maxillary and premaxillary teeth in the absence of vomerine teeth (92

95 species), but only two species examined have vomerine teeth while lacking upper jaw teeth

96 (Rhombophryne testudo, Uperodon systoma).

97 All 65 salamander species examined have teeth on the lower jaw and palate, but three

98 species lack upper jaw teeth on the maxilla and premaxilla (the sirenids Siren intermedia and

99 Pseudobranchus striatus and the salamandrid Salamandrina terdigitata). Thorius pennatulus

100 (Plethodonidae) and two proteids (Necturus lewisi and Proteus anguinus) lack maxillary teeth

101 but retain premaxillary teeth. All salamanders have vomerine teeth on the palate (including the

102 paravomerine tooth patches that underlie the parasphenoid in plethodontids (Fig. 1C); Lawson

103 et al. 1971). Palatal teeth were additionally observed on the palatopterygoid (Necturus lewisi

104 and Proteus anguinus) and palatine (Siren intermedia and Pseudobranchus striatus). The lower

105 jaw teeth are present on the dentary in all species, except Siren intermedia and

106 Pseudobranchus striatus, which have mandibular teeth on the splenial. Necturus lewisi and

107 Proteus anguinus are the only two species that have lower jaw teeth on both the dentary and

108 splenial. 
All 30 caecilian species examined possess teeth on the lower jaw, upper jaw, and palate

110 (Fig. 1D). The individual elements of the lower jaw in caecilians fuse to form the pseudodentary,

111 and this composite element varies in having either one or two rows of teeth. Upper jaw teeth are

112 present on the nasopremaxilla (fused nasal and premaxilla) and maxillopalatine (fused maxilla

113 and palatine; outer row). Palatal teeth are always present on the vomer and maxillopalatine

114 (inner row) and occur on the ectopterygoid in one species (Geotrypetes seraphini).

\section{Repeated Tooth Loss in Frogs}

116 Teeth are absent in 134 anuran genera belonging to 19 families. We used reversible-jump

117 Markov chain Monte Carlo (MCMC) in RevBayes (Höhna et al. 2016) to sample all five Markov

118 models of phenotypic character evolution in proportion to their posterior probability. The

119 maximum a posteriori model of dentition evolution was the one-rate model with a posterior

120 probability of 0.91 . The model-averaged maximum a posteriori ancestral state of Lissamphibia

121 and Anura is toothed with a posterior probability of 0.99 . Teeth have been completely lost at

122 least 22 times in frogs (Fig. 2), and six reversals from edentulous to toothed upper jaws were

123 inferred. Edentulism has evolved three times in Mesobatrachia, 12 times in Hyloidea, six times

124 in Ranoidea, and once in Nasikabatrachidae. One reversal was estimated in Myobatrachidae (in

125 Uperoleia mahonyi; Clulow et al. 2016) and five reversals were inferred in Microhylidae (in

126 Dyscophus, Uperodon, Anodonthyla, Cophyla, and Rhombophryne + Plethodontohyla). 


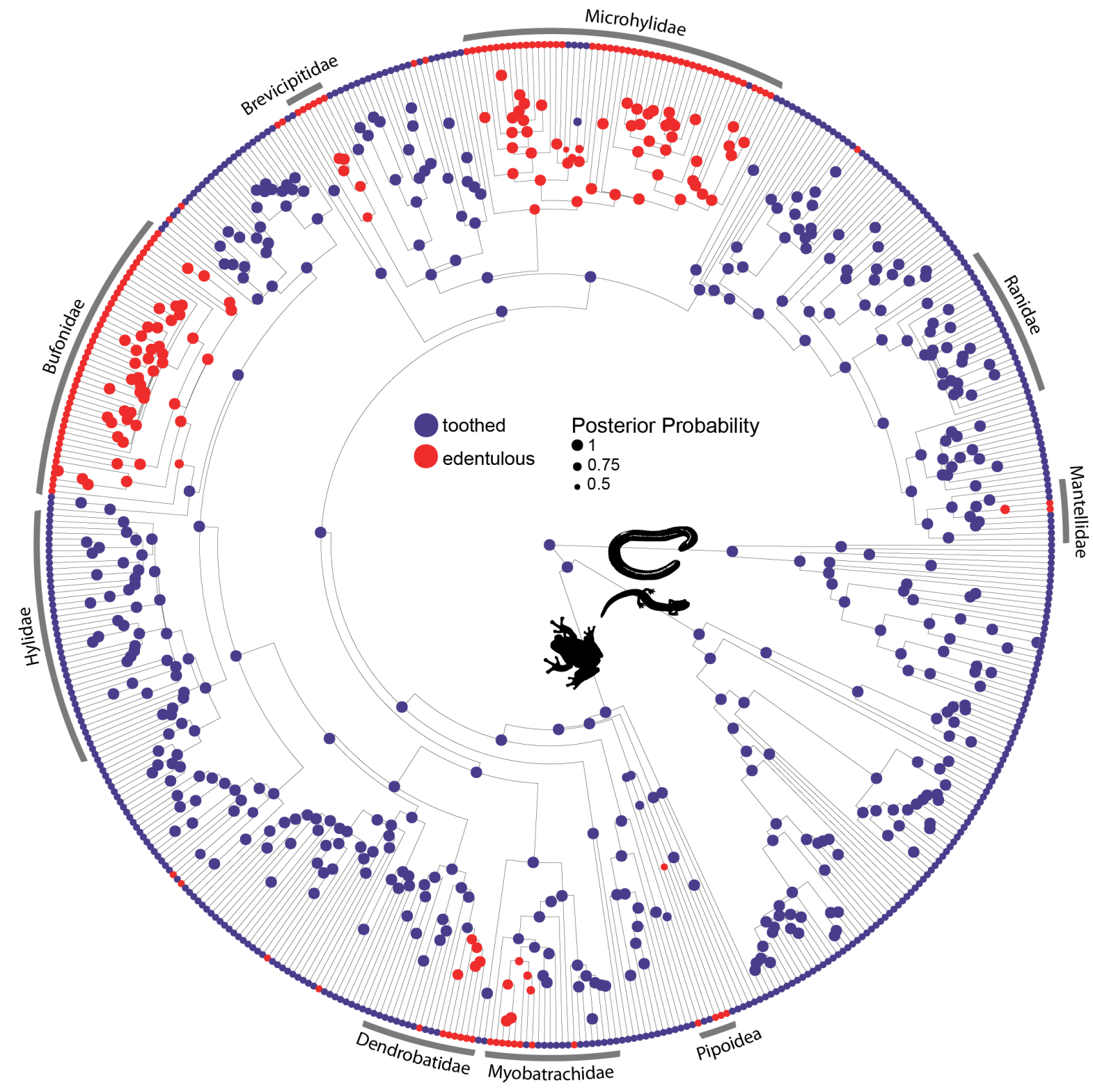

Figure 2. Phylogeny of 524 amphibians depicting the evolution of dentition. Node point color corresponds to Bayesian model-averaged ancestral states of dentition: blue = toothed; red = edentulous. The size of each node point represents the posterior probability of the most probable ancestral state. Tip point colors correspond to dentition states for all species. For species tip labels display Figure 1-figure supplement 1. For Bayesian model-averaged ancestral states of tooth presence/absence on individual dentigerous elements display Figure 1-figure supplements 2-5. Corresponding data are provided in Dataset S1. 
128 Relationships among tooth loss, diet, and body size

129 We compiled published diet records for 267 frog lineages and classified 69 taxa from 20 families

130 as microphagous and 198 taxa from 47 families as generalist feeders (Fig. 3; Dataset S2). Of

131 the 69 microphagy specialists, 53 are edentulous and 16 are toothed. Of the 198 generalists, 26

132 are edentulous and 172 are toothed. A BayesTrait discrete analysis indicated correlated

133 evolution between edentulism and microphagy: the dependent model of trait evolution is

134 strongly supported over the independent model (Bayes factor $=46.97$; a Bayes factor $>2$

135 implies the evolution of two traits is linked). Similar results were found using a 158-taxon dataset

136 excluding genus-level diet data (Bayes factor $=26.26)$. Of the 22 independent losses of teeth

137 across frogs, at least 16 of these lineages contain microphagous species (Fig. 3). The majority

138 of the 26 taxa classified as both edentulous and generalist feeders are members of the

139 Bufonidae and Microhylidae, but also includes the fully aquatic pipids Pipa and Hymenochirus,

140 two brevicipitids (Probreviceps and Callulina), and the Darwin's frog, Rhinoderma.

141 The relative jaw length in frogs ranges from $62 \%$ of head length in Synapturanus

142 mirandaribeiroi, an edentulous microhylid, to $140 \%$ of head length in Lepidobatrachus asper, a

143 toothed ceratophryid. A phylogenetic logistic regression showed a significant relationship

144 between edentulism and shortened jaws (alpha $=0.0011$, standard error $=0.8920, P<0.001$;

145 Fig. 4A). Edentulous species have an average relative jaw length of $83 \%$ of head length, while

146 toothed species have an average relative jaw length of $99 \%$ of head length. Nearly all

147 edentulous species examined have an anteriorly shifted jaw joint (lower jaw length is shorter

148 than respective head length; the two largest bufonids in our dataset, Bufo gargarizans and

149 Rhaebo blombergi, are exceptions), but over 100 toothed taxa have posteriorly shifted jaws

150 (lower jaws that are longer than their heads; Fig. 4A). The snout-vent length (SVL) of

151 specimens measured ranges from $7.8 \mathrm{~mm}$ in the edentulous Paedophryne amauensis, the 


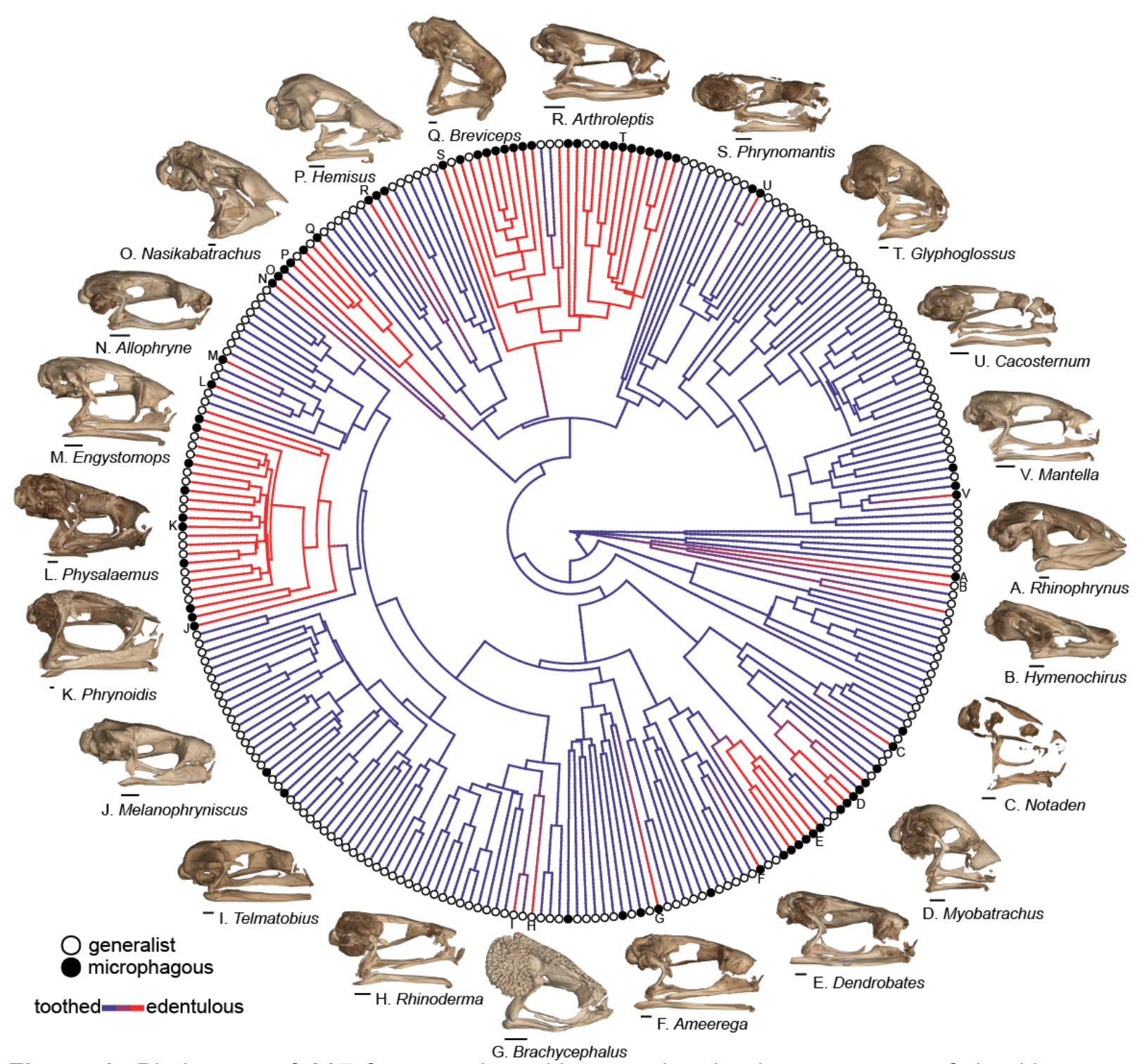

Figure 3. Phylogeny of 267 frog species with a stochastic character map of dentition states (phytools, Revell 2012) and distribution of generalist and microphagous diet states (tip point colors) illustrating the correlated evolution of edentulism and microphagy. Diversity of edentulous frog skulls: A. Rhinophrynus dorsalis (CAS:Herp:71766), B. Hymenochirus boettgeri (CAS:Herp:253587), C. Notaden bennetti (CAS:Herp:78115), D. Myobatrachus gouldii (MCZ:Herp:139543), E. Dendrobates tinctorius (YPM:Vz:010610), F. Ameerega trivittata (UF:Herp:107200), G. Brachycephalus ephippium (UF:Herp:72725), H. Rhinoderma darwinii (UF:Herp:62022), I. Telmatobius carrillae (UF:Herp:39717), J. Melanophryniscus stelzneri (UF:Herp:63183), K. Phrynoidis asper (USNM:Amphibians \& Reptiles:586870), L. Physalaemus nattereri (MCZ:Herp:A30113), M. Engystomops pustulosus (CAS:Sua:21892), N. Allophryne ruthveni (KU:Kuh:166716), O. Nasikabatrachus sahadryensis (CES:F:203), P. Hemisus guineensis (CAS:Herp:258533), Q. Breviceps gibbosus (AMNH:Herpetology:3053), $\mathbf{R}$. Arthroleptis schubotzi (CAS:Herp:201762), S. Phrynomantis annectens (AMB:10086), T. Glyphoglossus molossus (CAS:Herp:243121), U. Cacosternum namaquense (CAS:Herp:156975), V. Mantella baroni (CAS:Herp:250387). Scale bars $=1 \mathrm{~mm}$. For species tip labels display Figure 2-figure supplement 1. Corresponding data are provided in Dataset S2. 
153 species. A phylogenetic logistic regression indicated that there is no relationship between

154 edentulism and body size (alpha $=0.0016$, standard error $=0.1162, P=0.09 ;$ Fig 4B).

155 Edentulous species have an average SVL of $36.2 \mathrm{~mm}$ (range 7.8-152.4 $\mathrm{mm}$ ) and toothed

156 species have an average SVL of 43.7 (range $11.2-263.9 \mathrm{~mm}$ ).

\section{Discussion}

\section{Evolution of edentulism in jawed vertebrates}

160 With at least 22 independent origins of edentulism, frogs have completely lost teeth more times

161 than any other vertebrate clade. Based on our review of the literature, only seven other extant

162 vertebrate lineages are entirely edentulous. There are no described edentulous chondrichthyan

163 species (but see Mulas et al. (2020) for the first described aberrant case in a catshark). To our

164 knowledge, teeth have been entirely lost only twice in living actinopterygian fishes in the

165 Syngnathidae (seahorses and pipefish; Lin et al. 2016) and the milkfish, Chanos chanos (Kohno

166 et al. 1996, Wang et al. 2017). Other fish lineages, such as the cyprinids, have toothless oral

167 jaws but retain true pharyngeal teeth (Aigler et al. 2014). Five extant amniote clades are

168 edentulous, including three lineages of mammals (baleen whales, pangolins, anteaters), all

169 living birds, and all living turtles (Davit-Béal et al. 2009). There are several mammal clades that

170 have lost enamel but retain reduced teeth (armadillos, sloths, aardvarks, pygmy and dwarf

171 sperm whales; Meredith et al. 2009). Molecular evidence suggests a single loss of teeth in the

172 common ancestor of extant birds (Meredith et al. 2014), but complete edentulism also evolved

173 independently in at least two extinct lineages of Mesozoic birds (Confuciusornis and Gobipteryx;

174 Yang and Snyder 2018). Teeth were completely lost in at least two lineages of non-avian

175 dinosaurs (ornithomimosaurs and caenagnathoids; Wang et al. 2017, Hendrickx et al. 2019) and

176 in some pterosaurs, such as members of Azhdarchidae (Yang and Snyder 2018). All living

177 crocodilians retain teeth, but at least two fossil suchian archosaurs were edentulous

178 (Shuvosaurus and Effigia; Nesbitt and Norell 2006). There are no known edentulous squamate 
species, although African egg-eating snakes in the genus Dasypeltis may have a dental

180 polymorphism, as they typically have small, short teeth but some individuals are reported to be

181 edentulous (Visser 1981). Lastly, at least one extinct rhynchocephalian has been suggested to

182 be edentulous (Sapheosaurus, Rauhut et al. 2012).

183 The loss of teeth may be associated with the evolution of a secondary feeding apparatus

184 (Davit-Béal et al. 2009, Wang et al. 2017), such as the keratinized beak in birds and turtles,

185 baleen in mysticete whales, and specialized tongues in pangolins and anteaters. Nearly all frogs

186 have a specialized tongue that is used in feeding (Regal and Gans 1976), and this adaptation

187 might have facilitated the repeated loss of teeth across anurans. Surprisingly, three anuran

188 lineages are both tongueless and edentulous (Hymenochirus, Pseudhymenochirus, and Pipa in

189 Pipidae), but these species are highly aquatic and have a derived mechanism of catching prey

190 under water through suction feeding (Dean 2003, Cundall et al. 2017). The edentulous

191 syngnathids (seahorses and relatives) and actinopterygians with toothless oral jaws also catch

192 prey through suction feeding (Roos et al. 2009, Mihalitsis and Bellwood 2019). There appears to

193 be no size-related constraints promoting complete tooth loss across all vertebrates. Edentulous

194 species span the entire spectrum of vertebrate body sizes: the smallest known vertebrate

195 species (the microhylid frog Paedophryne amauensis, Rittmeyer et al. 2012) and the largest (the

196 blue whale, Balaenoptera musculus) are both edentulous. The second-smallest known

197 vertebrate, the cyprinid fish in the genus Paedocypris, retain true pharyngeal teeth (Kottelat et

198 al. 2006). Several edentulous vertebrate clades are thought to have paedomorphic skulls,

199 including toothless frogs (Smirnov and Vasil'eva 1995), birds (Bhullar et al. 2012), and baleen

200 whales (Fordyce and Barnes 1994), suggesting that tooth loss in vertebrates may be a

201 byproduct of truncated development, but this hypothesis requires further investigation.

202 Tooth formation occurs ontogenetically late in frogs, during or after metamorphosis, in

203 contrast to during early larval or embryonic development in other vertebrates (Davit-Béal et al.

204 2007, Lainoff et al. 2015). This delayed shift in odontogenesis may be linked to the evolutionary 
205 lability of teeth in anurans. There may also be a relationship between the loss of teeth and 206 delayed ossification of dentigerous elements. For example, the dentary bone ossifies relatively

207 late in frogs, and nearly always lacks teeth, compared to being one of the first cranial elements

208 to ossify in salamanders and caecilians (Harrington et al. 2013), and these amphibians always

209 retain mandibular dentition. The anuran mouth undergoes dramatic restructuring during

210 metamorphosis while transitioning from an herbivorous tadpole with a keratinized beak and

211 short, cartilaginous lower jaw to a carnivorous frog with an elongated, bony lower jaw. This rapid

212 morphological transformation requires further study in edentulous and toothed species. Several

213 anuran lineages have evolved direct development (undergoing the larval stage within the egg;

214 Gomez-Mestre et al. 2012), and this life history transition may provide an opportunity to

215 repattern the jaw and alter dental development.

\section{Amphibian dentition and tooth loss in frogs}

217 Dentition is highly conserved in salamanders and caecilians with no identified cases of

218 edentulism. Teeth are present on the jaws and palate of all caecilians (Wake and Wurst 1979),

219 and this is also the typical dental condition in salamanders (Gregory et al. 2016). The aquatic

220 sirenid salamanders (Siren, Pseudobranchus) lack maxillary and premaxillary teeth (Clemen

221 and Greven 1988), while the miniaturized species of Thorius sampled here (T. pennatulus) lacks

222 maxillary teeth but retains teeth on the premaxilla, palate, and lower jaw. At least one species of

223 Thorius possesses a novel dental polymorphism in which males lack maxillary teeth but females

224 maintain several teeth on the maxilla (Hanken et al. 1999). To our knowledge, this is the only

225 known case of a sexually dimorphic presence/absence dental polymorphism in an amphibian.

226 Larval salamanders and caecilians were excluded in our dentition survey but differ in patterns of

227 dentition from adults (Wake 1976, Clemen and Gren 2018), such as the transient presence of

228 teeth on the splenials, palatines, and pterygoids that are lost during development (Schoch et al.

229 2019). Maxillary and premaxillary teeth are synchronized in all anuran taxa that we sampled, but

230 two species in the genus Telmatobius have maxillary teeth in the absence of premaxillary teeth 
231 (Barrionuevo 2017). Members of this genus can be toothed or edentulous, and two species are

232 reported to have intraspecific variation in the presence or absence of dentition (Barrionuevo

233 2017). Vomerine teeth are not coordinated with dentition on the upper jaw in frogs, are the most

234 variable across the sampled anuran genera, and their lability requires further study. Previous

235 work has suggested that the size and number of vomerine teeth may be correlated with diet and

236 body size (Hedges 1989, Estrada and Hedges 1996). Teeth are entirely absent in 134 anuran

237 genera distributed across 19 families, and our ancestral state reconstruction suggests that teeth

238 have been lost more than 20 times during the evolution of frogs.

239 We identified a phylogenetic correlation between the evolution of edentulism and a

240 microphagous diet, and these two traits co-occur in more than 50 genera belonging to 14

241 families (Dataset S2; Fig. 3). The majority of these species specialize on eating ants and

242 termites, despite that these insects have many defense behaviors (biting, stinging, chemical

243 weapons) and low nutritional value compared to other invertebrates (Redford and Dorea 1984,

244 McNab 1984). Edentulous, microphagous frogs inhabit biomes ranging from tropical forests

245 (e.g., Dendrobates, Mantella, Cardioglossa) to arid deserts (e.g., Breviceps, Notaden) and are

246 found on all continents, excluding Antarctica. Frogs, ants, and termites evolved at roughly the

247 same time-with important diversification events occurring in all three groups during the

248 Cretaceous and Cretaceous-Paleogene boundary (Moreau and Bell 2013, Bourguignon et al.

249 2014, Feng et al. 2017)—suggesting the repeated evolution of complete edentulism in frogs

250 may be linked to the spatiotemporal diversification of ants and termites. Teeth have been

251 repeatedly reduced in other tetrapods that specialize on eating ants and termites, including

252 multiple lineages of mammals (echidnas, numbats, aardvarks, aardwolves, anteaters,

253 armadillos, pangolins; Reiss 2001) and squamates (scolecophidian blind snakes, Aprasia worm

254 lizards; Daza and Bauer 2015). 
The complete loss of teeth in frogs is associated with the shortening of the lower jaw

(Fig. 4), a skeletal trait that is known to occur in species that eat smaller prey (Emerson 1985,

257 Vidal-Garcia and Keogh 2017, Paluh et al. 2020). The shortening of the mandible reduces

258 maximum gape and alters jaw biomechanics to improve the efficiency of catching many small

259 prey items. Frogs with a jaw length equal to or longer than the skull have an asymmetrical

260 feeding cycle where the time spent catching prey is short but the time spent bringing prey into

261 the mouth is long (Gans and Gorniak 1982); shortened jaws result in a faster, symmetric feeding

262 cycle where equal amounts of time are spent catching and bringing prey into the mouth

263 (Emerson 1985). At least four lineages of edentulous anurans that specialize on ants and

264 termites have additionally evolved muscular hydrostatic tongues that can be aimed in all three

265 dimensions and with great precision without moving the head to improve the efficiency of small

266 prey capture (Rhinophrynus, Trueb and Gans 1983; Hemisus, Nishikawa et al. 1999;

267 microhylids and brevicipitids, Meyers et al. 2004). Frog species that feed inside ant and termite

268 colonies may also possess improved abilities to process olfactory and tactical cues in order to

269 detect and localize prey (Deban et al. 2001).
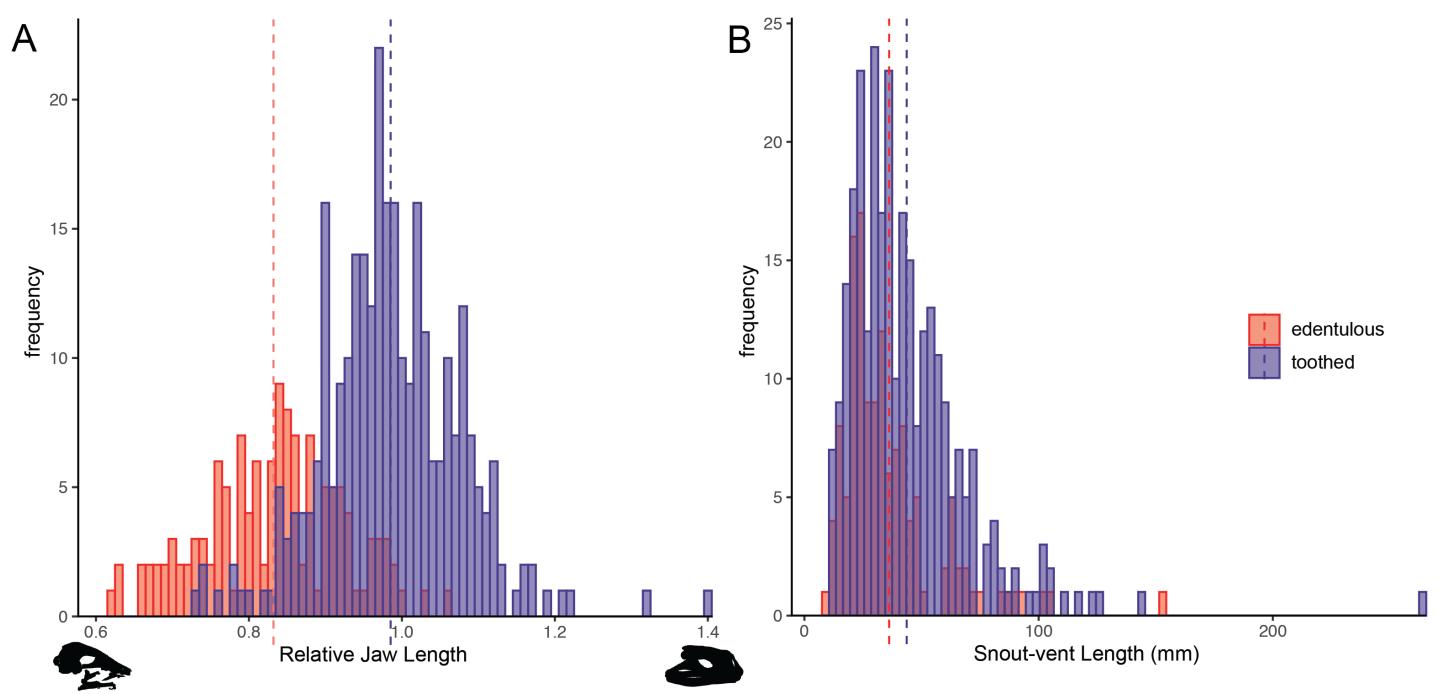

Figure 4. Histograms of relative jaw length (mandible length divided by skull length; $\mathbf{A}$ ) and body size (snout-vent length; B) in 423 frog species plotted by dentition states (blue = toothed; red = edentulous). A phylogenetic correlation was identified between tooth loss and shortened lower jaws. There is no association between edentulism and body size. Left skull silhouette is Hemisus guineensis (CAS:Herp:258533) and right skull is Lepidobatrachus asper (UF:Herp:12347). Corresponding trait data are provided in Dataset S3. 
The majority of the 134 edentulous frogs in our dataset are restricted to the families

271 Bufonidae and Microhylidae. All 48 genera of bufonids examined—the only anuran clade widely

272 recognized as being edentulous (Davit-Béal et al. 2009)_and 48 of 54 of microhylid genera

273 examined lack teeth. All remaining families have less than ten edentulous genera. The

274 Bufonidae and Microhylidae are two of the most diverse frog families, comprising 638 and 695

275 species, respectively (18\% of all frogs; AmphibiaWeb 2021). The evolution of edentulism in

276 frogs may exert an influence on diversification rates, but we refrain from testing this hypothesis

277 using trait-dependent diversification models due to our sparse, genus-level taxonomic sampling

278 (429 tips representing 7,299 lineages). The results of our ancestral state reconstruction

279 analyses indicate that teeth were independently lost in the most recent common ancestors of

280 both bufonids and microhylids. Once lost, teeth have not been regained in the Bufonidae but

281 may have re-evolved several times in microhylids. Although both clades have many taxa that

282 specialize on microphagous prey, there are bufonids and microhylids with expanded,

283 generalized diets, and a few species that will even consume vertebrate prey (e.g., Rhinella

284 marina, Asterophrys turpicola). The variation in diet within bufonids and microhylids corresponds

285 with variation in the relative length of the lower jaw (Dataset S3) and overall skull morphology

286 (Paluh et al. 2020).

The inferred reversals in Microhylidae occur in Dyscophus, Uperodon, and four

288 cophyline genera (Anodonthyla, Cophyla, Plethodontohyla, Rhombophryne). Recent work has

289 also suggested that additional microhylid genera contain toothed and edentulous species (Mini,

290 Scherz et al. 2019; Glyphoglossus, Gorin et al. 2021). If teeth were entirely lost in the common

291 ancestor of microhylids, the repeated re-evolution of true teeth (with enamel, dentin, and pulp

292 cavity) in this clade is unlikely and requires histological investigation. We hypothesize the tooth-

293 like structures in these taxa may be small odontoid serrations, similar to what has been

294 described in some Brachycephalus (Ribeiro et al. 2017) and New Guinea asterophrynine

295 microhylids (Zweifel 1971). The dental anatomy of Dyscophus has been examined (LaDouceur 
296 et al. 2020), and this genus does possess true teeth. The phylogenetic relationships among

297 microhylid taxa remain controversial (Peloso et al. 2016, Streicher et al. 2020), which further

298 impedes the interpretation of dental evolution in this group.

299 Of the nine anuran genera known to possess variation in the presence or absence of

300 teeth, diet data are only available for Physalaemus and Engystomops. In both genera,

301 edentulous species have specialized microphagous diets in comparison to toothed congeners

302 that consume a broader array of invertebrates (Narváez and Ron 2013). Dietary alkaloid

303 sequestration has evolved as a predator defense mechanism in at least five clades of frogs that

304 specialize on eating ants and mites, and teeth have been lost in several of these lineages

305 (Dendrobatinae and Ameerega [Dendrobatidae, Saporito et al. 2004]; Pseudophryne

306 [Myobatrachidae, Smith et al. 2002]; Mantella [Mantellidae, Daly et al. 1997]; Melanophryniscus

307 [Bufonidae, Hantak et al. 2013]). Teeth are retained in Phyllobates, which is sister to all other

308 edentulous genera of the Dendrobatinae, and in the Cuban Eleutherodactylus group known to

309 sequester alkaloids (Rodríguez et al. 2010). There are other microphagous frogs that retain

310 teeth, such as the ant specialist Sphaenorhynchus (Parmelee 1999). Further work is needed to

311 investigate the number, size, and histological anatomy of teeth across toothed frogs that vary in

312 diet. It remains unknown whether any anurans have lost enamel but retain teeth, which has

313 occurred several times in mammals (Meredith et al. 2009).

$314 \quad$ No relationship was identified between complete edentulism and body size in the 423

315 frog species sampled. The smallest known species of frog, Paedophryne amauensis, lacks

316 teeth, but some miniaturized anurans are toothed. We examined 25 taxa with a SVL of $15 \mathrm{~mm}$

317 or less: 13 were toothed and 12 were edentulous. Several of the smallest edentulous species in

318 our dataset are microhylids, bufonids, and dendrobatids, and these clades have widespread

319 tooth loss across a range of body sizes. We identified only one case of edentulism in

320 Brachycephaloidea, in the genus Brachycephalus, despite that this new world radiation of over

3211,000 species contains many miniaturized lineages (e.g., smallest members of Pristimantis, 
322 Eleutherodactylus, Noblella). Within the genus Arthroleptis, several miniature species lack teeth

323 (Laurent 1954; Blackburn 2008), suggesting that, in some cases, a reduction in body size and

324 tooth loss may be linked. There are several large or gigantic species within the Bufonidae

325 (Womack and Bell 2020), but all true toads lack teeth regardless of size.

\section{Tooth loss in fossil frogs}

327 Several crown-group fossil frogs have been described that are edentulous, including Theatonius

328 lancensis (Fox 1976), Tyrrellbatrachus brinkmani (Gardner 2014), Saltenia (Baez 1981), and

329 Vulcanobatrachus (Trueb et al. 2005) from the Late Cretaceous, and Chelomophrynus bayi from

330 the Eocene (Henrici 1991). The majority of these taxa have been hypothesized to be members

331 of the Pipoidea. Of the stem salientians with cranial material, teeth are present on the upper jaw

332 in Prosalirus (Shubin and Jenkins 1995), Vieraella (Báez and Basso 1996), and Liaobatrachus

333 (Gao and Wang 2001). No teeth are visible in Triadobatrachus (Ascarrunz et al. 2016), the

334 oldest known stem frog, but the maxilla and premaxilla are poorly preserved in this impression

335 fossil. The dentary of Triadobatrachus lacks teeth, and the absence of dentition on the lower jaw

336 is considered a synapomorphy of Salientia (Milner 1988). To our knowledge, no stem tetrapods

337 have been described as edentulous (Ruta et al. 2003, Anderson et al. 2008, Matsumoto and

338 Evans 2017). Albanerpetontids, an extinct lineage of lissamphibians, retained teeth (Daza et al.

339 2020).

340 Molecular and developmental mechanisms of tooth loss.

341 Recent work has documented that several lineages of edentulous vertebrates have various

342 states of molecular tooth decay in the genes that are critical for the formation of dentin and

343 enamel with frameshift mutations and stop codons that result in nonfunctionalization (mammals:

344 Meredith et al. 2009; turtles: Meredith et al. 2013; birds: Meredith et al. 2014; syngnathids: Lin et

345 al. 2016). The frameshift mutation rate of these loci can be used to estimate the timing of tooth

346 loss in the fossil record (Meredith et al. 2009, 2014), and the ratio of synonymous and

347 nonsynonymous substitutions can be calculated to measure selection pressure on enamel 
matrix proteins (Alazem and Abramyan 2019). Whether edentulous frogs possess similar rates of molecular tooth decay in these loci, as demonstrated in amniotes, has yet to be tested. We hypothesize that these tooth-specific genes have degenerated repeatedly across edentulous anurans by novel inactivating mutations, and the frameshift mutation rate will indicate that teeth were lost at several different geologic times during the evolution of frogs. Anuran enamel matrix proteins may be operating under relaxed selection, compared to purifying selection in most mammals and reptiles (Alazem and Abramyan 2019), due to the evolution of projectile tongue

355 feeding, enabling the evolutionary lability of frog teeth. unexplored, especially when compared to our understanding of chondrichthyan, teleost, and

358 amniote odontogenesis (Fraser et al. 2004, Tucker and Sharpe 2004, Thiery et al. 2017). It is unknown if the genes critical for tooth formation in fishes and amniotes are also expressed during morphogenesis of teeth in amphibians, if all frog species retain a suppressed ancestral developmental pathway of tooth development on the lower jaw, or if the odontogenetic pathway

362 has been disrupted via one or many mechanisms on the jaws of edentulous anurans. The loss

363 of teeth on the lower jaw of frogs could be due to the loss of a single major signal that can

364 orchestrate odontogenesis, comparable to the sole loss of odontogenic Bmp4 expression in

365 living birds (Chen et al. 2007) or termination of Msx2 expression in living turtles (Tokita et al.

366 2012), which arrests tooth formation early in development. If true, potential rudimentary

367 structures, such as tooth buds or the early thickening of the odontogenic band, might be seen

368 before the abortion of tooth development in the lower jaw of anurans. Investigation of the

369 developmental genetics of tooth formation in the upper and lower jaws of frogs will fill a large

370 gap in our understanding of vertebrate evolution and development and may elucidate the

371 mechanisms of repeated tooth loss and putative cases of the re-evolution of lost teeth in one of

372 the most diverse vertebrate orders. 


\section{Methods}

\section{Species Sampling and scanning.}

375 We collected data from high-resolution micro-computed tomography (microCT) scans of 523

376 amphibian species, representing 420 frog genera (of 461 total; AmphibiaWeb 2021), 65

377 salamander genera (of 68 total), and 30 caecilian genera (of 34 total). One recently described

378 frog species was not CT scanned but included in the dataset because it is the only member of

379 its genus with teeth (Uperoleia mahonyi; Clulow et al. 2016). All genera are represented by one

380 species except for nine anuran genera (Arthroleptis, Cacosternum, Engystomops, Gastrotheca,

381 Physalaemus, Pipa, Telmatobius, Uperodon, Uperoleia) with two sampled lineages that

382 represent known dental variation within these genera (Dataset S1). All scans were run using a

$383240 \mathrm{kv}$ x-ray tube containing a diamond-tungsten target, with the voltage, current, and detector

384 capture time adjusted for each scan to maximize absorption range for each specimen. Raw x-

385 ray data were processed using GE's proprietary datos|x software version 2.3 to produce a

386 series of tomogram images and volumes, with final voxel resolutions ranging from 1 to $147 \mu \mathrm{m}$.

387 The resulting microCT volume files were imported into VG StudioMax version 3.2.4 (Volume

388 Graphics, Heidelberg, Germany), the skull and skeleton were isolated using VG StudioMax's

389 suite of segmentation tools, and then exported as high-fidelity mesh files. We deposited image

390 stacks (TIFF) and 3D mesh files of the skull and skeleton for each specimen in MorphoSource

391 (see Dataset S1 for DOls).

\section{Survey of amphibian dentition variation and ancestral state reconstructions.}

393 We recorded the presence or absence of teeth on each dentigerous bone of the lower jaw,

394 upper jaw, and palate for 524 amphibian species (Fig. 1; Dataset S1). We conducted ancestral 395 state reconstructions of dentition (two states: toothed, edentulous) in extant amphibians using

396 the data collected from 524 species representing 515 genera and all 77 families and the

397 phylogeny of Jetz and Pyron (2018). Bayesian ancestral state reconstructions were calculated

398 using reversible-jump MCMC in RevBayes (Höhna et al. 2016) to sample all five Markov models 
399 of phenotypic character evolution (one-rate, two-rate, zero-to-one irreversible, one-to-zero

400 irreversible, no change) in proportion to their posterior probability. We accounted for model

401 uncertainty by making model-averaged ancestral state estimates (Freyman and Höhna 2018,

402 Freund et al. 2018). The models were assigned an equal prior probability using a uniform set-

403 partitioning prior, and the root state frequencies were estimated using a flat Dirichlet prior. The

404 rates of gain and loss of dentition were drawn from an exponential distribution with a mean of 10

405 expected character state transitions over the tree. The MCMC was run for 22,000 iterations, the

406 first 2,000 iterations were discarded as burn-in, and samples were logged every 10 iterations.

407 Convergence of the MCMC was confirmed using Tracer v1.6 to ensure that analyses had

408 reached stationarity. We conducted additional ancestral state reconstructions to model the

409 evolutionary history of dentition presence/absence on individual dentigerous elements (Figure

410 1-figure supplements 2-5).

\section{Testing relationships among edentulism, diet, and body size.}

412 We compiled dietary data for all sampled anuran species from the literature (see Dataset S2 for

413 references). Species were classified as microphagous specialists if the majority (>50\%) of their

414 diet by number or volume consists of ants, termites, or mites. Species were classified as

415 generalists if the majority of their diet by number or volume consists of other invertebrate groups

416 or vertebrates. For species with no published diet records, we searched for any existing diet

417 records at the genus level. Due to the disparity in existing ecological data available across all

418 anurans, the dietary records ranged from singular reports (one prey item in one individual) to

419 detailed studies investigating the stomach contents of dozens of individuals through space and

420 time.

421 We measured snout-vent length (SVL; tip of the snout to the rear of the ischium), skull

422 length (occiput to tip of the snout) and mandible length (posterior to anterior tip of the lower jaw)

423 for all sampled specimens using the linear measurement tools in VG StudioMax and MeshLab

424 (Cignoni et al. 2008). We calculated relative jaw length (mandible length divided by skull length) 
425 for each specimen: a jaw length value greater than one indicates a posteriorly shifted jaw joint

426 (lower jaw is longer than the head) and a value less than one indicates an anteriorly shifted jaw

427 joint (lower jaw is shorter than the head).

428 We used phylogenetic comparative methods to test for evolutionary correlations among

429 dentition, diet, and body size in frogs. We compiled diet records for 267 taxa, representing 258

430 genera and 52 anuran families: 158 species in the dentition dataset had published diet records

431 and the remaining 109 lineages are represented by genus-level diet data. We excluded the

432 remaining 162 anuran species in the dentition dataset (55 edentulous, 107 toothed) from the

433 diet analyses due to the lack of known diet records at the species or genus level. Because

434 dentition (toothed/edentulous) and diet (generalist/microphagous) were treated as binary traits,

435 we tested for a phylogenetic correlation using discrete independent and discrete dependent

436 models with rjMCMC sampling in BayesTraits v3.0.2 (Pagel and Meade 2006). The stepping

437 stone sampler for marginal likelihood reconstructions was used with 100 stones and 1000

438 iterations. The branch lengths were scaled to have a mean of 0.1 using ScaleTrees. Bayes

439 factors (Log BF = 2(log marginal likelihood complex model - log marginal likelihood simple

440 model)) were used to compare the fit of the independent versus dependent models. Models

441 were run using the complete 267 taxon dataset and a reduced 158 taxon dataset excluding

442 genus-level diet data.

443 Several previous studies have demonstrated a correlation between skull shape and diet

444 in frogs: species that specialize on small prey have anteriorly shifted, relatively short jaws while

445 generalist feeders that are capable of eating large prey have a posteriorly shifted jaw joint

446 (Emerson 1985, Vidal-Garcia and Keogh 2017, Paluh et al. 2020). Because diet data are

447 lacking for many anuran genera, we additionally tested for a phylogenetic correlation between

448 dentition and the relative length of the jaw as a morphological proxy for diet. Lastly, because

449 teeth may be lost as a byproduct of miniaturization (Hanken and Wake 1993, Smirnov and

450 Vasil'eva 1995), we tested for a phylogenetic correlation between dentition state and body size 
451 (SVL). Phylogenetic logistic regression models were calculated in the phylolm R package (Ho

452 and Ané 2014) using dentition and measurement data for 423 anuran species. Dentition

453 (toothed/edentulous) was treated as the binary response variable and the log transformed size

454 metrics (relative jaw length, SVL) as continuous predictor variables. We used the

455 "logistic_MPLE" method, which maximizes the penalized likelihood of the logistic regression,

456 with a btol of 10 , a log.alpha.bound of 10 , and 1,000 bootstrap replicates.

458 Acknowledgments

459 We thank all of the institutions, curators, and collection managers that loaned us specimens for

460 this study. We thank Marta Vidal-Garcia for providing access to the Spicospina flammocaerulea

461 scan. We thank the D.C.B. laboratory at the Florida Museum of Natural History for helpful

462 comments that improved an earlier version of this manuscript.

464 Funding

465 This material is based upon work supported by the NSF Graduate Research Fellowship to

466 D.J.P. under Grants DGE-1315138 and DGE-1842473. Computed tomography scans used in

467 this project were generated from the oVert NSF Thematic Collections Network (Grant DBI-

468 1701714) and the University of Florida.

$470 \quad$ Competing interests

471 The authors have no competing interest to declare.

\section{Data Availability Statement.}

474 Computed tomography data (tiff stacks and mesh files) have been deposited in MorphoSource

475 (see Dataset 1 for DOls). Data and scripts for all analyses are available on GitHub at

476 https://github.com/dpaluh/edentulous frogs. 


\section{References}

Aigler, S.R., D. Jandzik, K. Hataa, K. Uesugi, D.W. Stock. 2014. Selection and constraint underlie irreversibility of tooth loss in cypriniform fishes. Proceedings of the National Academy of Sciences 111: 7707-7712.

Alazem, O., J. Abramyan. 2019. Reptile enamel matrix proteins: selection, divergence, and functional constraint. Journal of Experimental Zoology B 2019: 1-13.

Anderson, J.S., R.R. Reisz, D. Scott, N.B. Fröbisch, S.S. Sumida. 2008. A stem batrachian from the Early Permian of Texas and the origin of frogs and salamanders. Nature 453: 515518.

Ascarrunz, E., J.C. Rage, P. Legreneur, M. Laurin. 2016. Triadobatrachus massinoti, the earliest known lissamphibian (Vertebrata: Tetrapoda) re-examined by $\mu C T-S c a n$, and the evolution of trunk length in batrachians. Contributions to Zoology 85: 201-234.

Báez, A.M. 1981. Redescription and relationships of Saltenia ibanezi, a Late Cretaceous pipid frog from northwestern Argentina. Ameghiniana 18: 127-154.

Báez, A.M., N. Basso. 1996. The earliest known frogs of the Jurassic of South America: Review and cladistic appraisal of their relationships. Münchner geowissenschaftliche Abhandlungen A 30: 131-158.

Blackburn, D.C. 2008. Evolution of diversity in African frogs (Arthroleptis and Cardioglossa). Ph.D. Dissertation, Harvard University, Cambridge, Massachusetts, 286 pp.

Barrionuevo, J.S. 2017. Frogs at the summits: phylogeny of the Andean frogs of the genus Telmatobius (Anura: Telmatobiidae) based on phenotypic characters. Cladistics 33: 4168.

Boulenger, G.A. 1882. Catalogue of the Batrachia Salientia s. Ecaudata in the collection of the British Museum. 2nd ed. London: Taylor and Francis.

Bourguignon, T., N. Lo, S.L Cameron, J. Šobotník, Y. Hayashi, S. Shigenobu, D. Watanabe, Y. Roisin, T. Miura, T.A. Evans. 2014. The evolutionary history of termites as inferred from 66 mitochondrial genomes. Molecular Biology and Evolution 32: 406-421.

Bhullar, B.-A. S., J. Marugán-Lobón, F. Racimo, G.S. Bever, T.B. Rowe, M.A. Norell, A. Abzhanov. 2012. Birds have paedomorphic dinosaur skulls. Nature 487: 223-226.

Caldwell, J.P. 1996. The evolution of myrmecophagy and its correlates in poison frogs (family Dendrobatidae). Journal of Zoology 240: 75-101.

Chen, Y., Y. Zhang, T.X. Jiang, A.J. Barlow, T.R. St. Amand, Y. Hu, S. Heaney, P. FrancisWest, C.-M. Chuong, R. Maas. 2000. Conservation of early odontogenic signaling pathways in Aves. Proceedings of the National Academy of Sciences 97: 10044-10049.

Cignoni, P., M. Callieri, M. Corsini, M. Dellepiane, F. Ganovelli, G. Ranzuglia. 2008. MeshLab: an Open-Source Mesh Processing Tool. Sixth Eurographics Italian Chapter Conference, 129-136.

Clemen, G., H. Greven, H. 1988. Morphological studies on the mouth cavity of Urodela. IX. Teeth of the palate and the splenials in Siren and Pseudobranchus (Sirenidae: Amphibia). Zeitschrift für zoologische Systematik und Evolutionsforschung 26: 135-143.

Clemen, G., H. Greven. 2018. Long-term effects of arrested metamorphosis on dental systems in Salamandra salamandra (Salamandridae: Urodela). Vertebrate Zoology 68: 143-155. 
Clulow, S., M. Anstis, J.S. Keogh, R.A. Catullo. 2016. A new species of Australian frog (Myobatrachidae: Uperoleia) from the New South Wales mid-north coast sandplains. Zootaxa 4184: 285-315.

Cope, E.D. 1867. On the families of the raniform Anura. Journal of the Academy of Natural Sciences of Philadelphia. Series 2. 6: 189-206.

Cundall, D., E. Fernandez, F. Irish. 2017. The suction mechanism of the pipid frog, Pipa pipa (Linnaeus, 1758). Journal of Morphology 278: 1229-1240.

Daly, J.W., H.M. Garraffo, G.S.E. Hall, J.F. Cover Jr. 1997. Absence of skin alkaloids in captiveraised Madagascan mantelline frogs (Mantella) and sequestration of dietary alkaloids. Toxicon 35: 1131-1135.

Das, I., M. Coe. 1994. Dental morphology and diet in anuran amphibians from south India. Journal of Zoology London 233: 417-427.

Davies, M. 1989. Ontogeny of bone and the role of heterochrony in the myobatrachine genera Uperoleia, Crinia, and Pseudophryne (Anura: Leptodactylidae: Myobatrachinae). Journal of Morphology 200: 269-300.

Davit-Béal, T., H. Chisaka, S. Delgado, J.-Y. Sire. 2007. Amphibian teeth: current knowledge, unanswered questions, and some directions for future research. Biological Reviews 82: 49-81.

Davit-Béal, T., AS Tucker, J-Y Sire. 2009. Loss of teeth and enamel in tetrapods: fossil record, genetic data and morphological adaptations. Journal of Anatomy 214: 477-501.

Daza, J.D., A.M. Bauer. 2015. Cranial anatomy of the pygopodid lizard Aprasia repens, a gekkotan masquerading as a scolecophidian. In: O.R.P. Emonds, G.L. Powell, H.A. Jamniczky, A.M. Bauer, J. Theordor, eds. All animals are interesting: a Festschrift in honour of Anthony P. Russell. Oldenburg: BIS-Verlag der Carl von Ossietzky Universität, pp. 303-350.

Daza, J.D., E.L. Stanley, A. Bolet, A.M. Bauer, J.S. Arias, A. Čerňanský, J.J. Bevitt, P. Wagner, S.E. Evans. 2020. Enigmatic amphibians in mid-Cretaceous amber were chameleon-like ballistic feeders 370: 587-691.

Dean, M.N. 2003. Suction feeding in the pipid frog, Hymenochirus boettgeri: Kinematic and behavioral considerations. Copeia 2003: 879-886.

Deban, S.M., J.C. O'Reilly, K.C. Nishikawa. 2001. The evolution of the motor control of feeding in amphibians. American Zoologist 41:1280-1298.

Duellman, W.E., L. Trueb. 1986. Biology of Amphibians. New York: McGraw-Hill Book Co.

Emerson, S.B. 1985. Skull shape in frogs-correlations with diet. Herpetologica 1985: 177-188.

Estrada, A.R., S.B. Hedges. 1996. At the lower size limit in tetrapods: A new diminutive frog from Cuba (Leptodactylidae: Eleutherodactylus). Copeia 1996: 852-859.

Feng, Y-J., D.C. Blackburn, D. Liang, D.M. Hillis, D.B. Wake, D.C. Cannatella, P. Zhang. 2017. Phylogenomics reveal rapid, simultaneous diversification of three major clades of Gondwanan frogs at the Cretaceous-Paleogene boundary. Proceedings of the National Academy of Sciences 114: E5864-E5870.

Fordyce, R.E., L.G. Barnes. 1994. The evolutionary history of whales and dolphins. Annual Review of Earth and Planetary Sciences 22: 419-455. 
561

562

563

564

565

566

567

568

569

570

571

572

573

574

575

576

577

578

579

580

581

582

583

584

585

586

587

588

589

590

591

592

593

594

595

596

597

598

599

600

601

602

603

604

Fox, R.C. 1976. An edentulous frog (Theatonius lancensis, new genus and species) from the Upper Cretaceous Lance Formation of Wyoming. Canadian Journal of Earth Sciences 13: $1486-1490$

Fraser, G.J., A. Graham, M.M. Smith. 2004. Conserved deployment of genes during odontogenesis across osteichthyans. Proceedings of the Royal Society B 271: 23112317.

Freund, F.D., W.A. Freyman, C.J. Rothfels. 2018. Inferring the evolutionary reduction of corm lobation in Isoëtes using Bayesian model-averaged ancestral state reconstruction. American Journal of Botany 105: 275-286.

Freyman, W.A., S. Höhna. 2018. Cladogenetic and anagenetic models of chromosome number evolution: A Bayesian model averaging approach. Systematic Biology 67: 195-215.

Gans, C., G. Gorniak. 1982. Functional morphology of lingual protrusion in marine toads (Bufo mariunus). American Journal of Anatomy 163: 195-222.

Gans, C., R.G. Northcutt. 1983. Neural crest and the origin of vertebrates: a new head. Science 220: 268-273.

Gao, K.-Q., Y. Wang. 2001. Mesozoic anurans from Liaoning Province, China, and phylogenetic relationships of archaeobatrachian anuran clades. Journal of Vertebrate Paleontology 21: $460-476$.

Gardner, J.D. 2014. An edentulous frog (Lissamphibia; Anura) from the Upper Cretaceous (Campanian) Dinosaur Park Formation of southeastern Alberta, Canada. Canadian Journal of Earth Sciences 52: 569-580.

Gomez-Mestre, I, R.A. Pyron, J.J. Wiens. 2012. Phylogenetic analyses reveal unexpected patterns in the evolution of reproductive modes in frogs. Evolution 66: 3687-3700.

Gorin, V.A., M.D. Scherz, D.V. Korost, N.A. Poyarkov. 2021. Consequences of parallel minaturisation in Microhylinae (Anura, Microhylidae), with the description of a new genus of diminutive South East Asian frogs. Zoosystematics and Evolution 97: 21-54.

Gregory, A.L., B.R. Sears, J.A. Wooten, C.D. Camp, A. Falk, K. O’Quin, T.K. Pauley. 2016. Evolution of dentition in salamanders: relative roles of phylogeny and diet. Biological Journal of the Linnean Society 119: 960-973.

Hanken, J., D.B. Wake. 1993. Miniaturization of body size: organismal consequences and evolutionary significance. Annual Review of Ecology, Evolution, and Systematics 24: 501-519.

Hanken, J., D.B. Wake, H.L. Freeman. 1999. Three new species of minute salamanders (Thorius: Plethodontidae) from Guerrero, México, including the report of a novel dental polymorphism in Urodeles. Copeia 1999: 917-931.

Hantak, M.M., T. Grant, S. Reinsch, D. McGinnity, M. Loring, N. Toyooka, R.A. Saporito. 2013. Dietary alkaloid sequestration in a poison frog: An experimental test of alkaloid uptake in Melanophryniscus stelzneri (Bufonidae). Journal of Chemical Ecology 39: 1400-1406.

Harrington, S.M., L.B. Harrison, C.A. Sheil. 2013. Ossification sequence heterochrony among amphibians. Evolution and Development 15: 344-364.

Hedges, S.B. 1989. Evolution and biogeography of West Indian frogs of the genus Eleutherodactylus: slow-evolving loci and the major groups. In C.A. Woods, ed., Biogeography of the West Indies: past present and future. Gainesville, Florida: Sandhill Crane Press, pp. 305-370. 
605

606

607

608

609

610

611

612

613

614

615

616

617

618

619

620

621

622

623

624

625

626

627

628

629

630

631

632

633

634

635

636

637

638

639

640

641

642

643

644

645

646

647

648

Hendrickx, C., O. Mateus, R. Araújo, J. Choiniere. 2019. The distribution of dental features in non-avian theropod dinosaurs: Taxonomic potential, degree of homoplasy, and major evolutionary trends. Palaeontologia Electronica 22: 1-110. doi:10.26879/820.

Henrici, A.C. 1991. Chelomophrynus bayi (Amphibia, Anura, Rhinophrynidae), a new genus and species from the middle Eocene of Wyoming: ontogeny and relationships. Annals of the Carnegie Museum 60: 97-144.

Hime, P.M., A.R. Lemmon, L.E.C. Moriarty, E. Prendini, J.M. Brown, R.C. Thomson, J.D. Kratovil, B.P. Noonan, R.A. Pyron, P.L.V. Peloso, M.L. Kortyna, J.S. Keogh, S.C. Donnellan, M.R. Lockridge, C.J. Raxworthy, K. Kunte, S.R. Ron, S. Das, N. Gaitonde, D.M. Green, J. Labisko, J. Che, D.W. Weisrock. Phylogenomics reveals ancient gene tree discordance in the amphibian tree of life. Systematic Biology 70: 49-66.

Ho, L.S.T., C. Ané. 2014. A linear-time algorithm for Gaussian and non-Gaussian trait evolution models. Systematic Biology 63: 397-408.

Höhna, S., M.J. Landis, T.A. Heath, B. Boussau, N. Lartillot, B.R. Moore, J.P. Huelsenbeck, F. Ronquist. 2016. RevBayes: Bayesian phylogenetic inference using graphical models and an interactive model-specification language. Systematic Biology 65: 726-736.

Jetz, W., R.A. Pyron. 2018. The interplay of past diversification and evolutionary isolation with present imperilment across the amphibian tree of life. Nature Ecology and Evolution 2: 850-858.

Kohno, H., R. Ordonio-Aguilar, A. Ohno, Y. Taki. Morphological aspects of feeding and improvement in feeding ability in early stage larvae of the milkfish, Chanos chanos. Ichthyological Research 43: 133-140.

Kottelat, M., R. Britz, T.H. Hui, K.-E. Witte. 2006. Paedocypris, a new genus of Southeast Asian cyprinid fish with a remarkable sexual dimorphism, comprises the world's smallest vertebrate. Proceedings of the Royal Society B 273: 895-899.

LaDouceur, E.E.B., A.M. Hauck, M.M. Garner, A.N. Cartoceti, B.G. Murphy. 2020. Odontomas in Frogs. Veterinary Pathology 57: 147-150.

Lainoff, A.J., J.E. Moustakas-Verho, D. Hu, A. Kallonen, R.S. Marcucio, L.J. Hlusko. 2015. A comparative examination of odontogenic gene expression in both toothed and toothless amniotes. Journal of Experimental Zoology B 324: 255-269.

Laurent, R.F. 1954. Remarques sur le genre Schoutedenella Witte. Annales du Musée Royal du Congo Belge, 4, Sciences Zoologiques, Tervuren 1: 34-40.

Lawson, R., D.B. Wake, N.T. Beck. 1971. Tooth replacement in the Red-backed Salamander, Plethodon cinereus. Journal of Morphology 134: 259-270.

Lin, Q., S. Fan, Y. Zhang, M. Xu, H. Zhang, Y. Yang, et al. 2016. The seahorse genome and the evolution of its specialized morphology. Nature 540: 395-399.

Matsumoto, R., S.E. Evans. 2017. The palatal dentition of tetrapods and its functional significance. Journal of Anatomy 230: 47-65.

McNab, B.K. 1984. Physiological convergence amongst ant-eating and termite-eating mammals. Journal of Zoology 203: 485-510.

Mihalitsis, M. D. Bellwood. 2019. Functional implications of dentition-based morphotypes in piscivorous fishes. Royal Society Open Science 6: 190040.

Milner, A.R. 1988. The relationships and origin of living amphibians. In M.J. Benton, ed., The phylogeny and classification of the Tetrapods. Oxford: Clarendon Press, pp 59-102. 
Meredith, R.W., J. Gatesy, W.J. Murphy, O.A. Ryder, M.S. Springer. 2009. Molecular decay of the tooth gene enamelin (ENAM) mirrors the loss of enamel in the fossil record of placental mammals. Plos Genetics 5: e1000634.

Meredith, R.W., J. Gatesy, M.S. Springer. 2013. Molecular decay of enamel matrix protein genes in turtles and other edentulous amniotes. BMC Evolutionary Biology 13: 20.

Meredith, R.W., G. Zhang, M.T.P. Gilbert, E.D. Jarvis, M.S. Springer. 2014. Evidence for a single loss of mineralized teeth in the common avian ancestor. Science 346: 1254390.

Meyers, J.J., J.C. O’Reilly, J.A. Monroy, K.C. Nishikawa. 2004. Mechanism of tongue protraction in microhylid frogs. Journal of Experimental Biology 207: 21-31.

Moreau, C.S., C.D. Bell. 2013. Testing the museum versus cradle biological diversity hypothesis: Phylogeny, diversification, and ancestral biogeographic range evolution of the ants. Evolution 67: 2240-2257.

Mulas, A., A. Bellodi, C. Porcu, A. Cau, E. Coluccia, R. Demurtas, M.F. Marongiu, P. Pesci, M.C. Follesa. 2020. Living naked: first case of lack of skin-related structures in an elasmobranch, the blackmouth catshark (Galeus melastomus). Journal of Fish Biology 97: 1252-1256.

Narváez, A.E., S.R. Ron. 2013. Feeding habits of Engystomops pustulatus (Anura: Leptodactylidae) in western Ecuador. South American Journal of Herpetology 8: 161167.

Nesbitt, S., M.A. Norell. 2006. Extreme convergence in the body plans of an early suchian (Archosauria) and ornithomimid dinosaurs (Theropoda). Proceedings of the Royal Society B 273: 1045-1048.

Nishikawa, K.C., W.M. Kier, K.K. Smith. 1999. Morphology and mechanics of tongue movement in the African pig-nosed frog Hemisus marmoratum: a muscular hydrostatic model. Journal of Experimental Biology 202: 771-780

Pagel, M., A. Meade. 2006. Bayesian analysis of correlated evolution of discrete characters by reversible-jump Markov chain Monte Carlo. The American Naturalist 167: 808-825.

Paluh, D.P., E.L. Stanley, D.C. Blackburn. 2020. Evolution of hyperossification expands skull diversity in frogs. Proceedings of the National Academy of Sciences 117: 8554-8562.

Parmelee, J.R. 1999. Trophic ecology of a tropical anuran assemblage. Scientific Papers, Natural History Museum, The University of Kansas 11: 1-59.

Peloso, P.L.V., D.R. Frost, S.J. Richards, M.T. Rodrigues, S. Donnellan, M. Matsui, et al. 2016. The impact of anchored phylogenomics and taxon sampling on phylogenetic inference in narrow-mouthed frogs (Anura, Microhylidae). Cladistics. 32:113-140

Rauhut, O.W.M., A.M. Heyng, A. López-Arbarello, A. Hecker. 2012. New Rhynchocephalian from the Late Jurassic of Germany with a Dentition That Is Unique amongst Tetrapods. Plos One 7: e46839.

Redford, K.H., J.G. Dorea. 1984. The nutritional value of invertebrates with emphasis on ants and termites as food for mammals. Journal of Zoology 203: 385-395.

Regal, P.J., C. Gans. 1976. Functional aspects of the evolution of frog tongues. Evolution 30: 718-734.

Reiss, K.Z. 2001. Using phylogenies to study convergence: the case of the ant-eating mammals. American Zoologist 41: 507-525. 
692

693

694

695

696

697

698

Revell, L.J. 2012. phytools: An R package for phylogenetic comparative biology (and other things). Methods in Ecology and Evolution 3: 217-223.

Ribeiro, L.F., D.C. Blackburn, E.L. Stanley, M.R. Pie, M.R. Bornschein. 2017. Two new species of the Brachycephalus pernix group (Anura: Brachycephalidae) from the state of Paraná, southern Brazil. PeerJ 5:e3603.

Rittmeyer, E.N., A. Allison, M.C. Gründler, D.K. Thompson, C.C. Austin. 2012. Ecological guild evolution and the discovery of the world's smallest vertebrate. Plos One 7: e29797.

Rodríguez, A., D. Poth, S. Schulz, M. Vences. 2010. Discovery of skin alkaloids in a miniaturized eleutherodactylid frog from Cuba. Biology Letters 7: 414-418.

Roos, G., S.V. Wassenbergh, A. Herrel, P. Aerts. 2009. Kinematics of suction feeding in the seahorse Hippocampus reidi. The Journal of Experimental Biology 212: 3490-3498.

Rücklin, M., P.C.J. Donoghue, Z. Johanson, K. Trinajstic, F. Marone, M. Stampanoni. 2012. Development of teeth and jaws in the earliest jawed vertebrates. Nature 491: 748-751.

Ruta, M., J.E. Jeffery, M.I. Coates. 2003. A supertree of early tetrapods. Proceedings of the Royal Society B 270: 2507-2516.

Saporito, R.A., H.M. Garraffo, M.A. Donnelly, A.L. Edwards, J.T. Longino, J.W. Daly. 2004. Formicine ants: An arthropod source for the pumiliotoxin alkaloids of dendrobatid poison frogs. Proceedings of the National Academy of Sciences 101: 8045-8050.

Scherz, M.D., C.R. Hutter, A. Rakotoarison, J.C. Riemann, M.-O. Rödel, S.H. Ndriantsoa, J. Glos, S.H. Roberts, A. Crottini, M. Vences, F. Glaw. 2019. Morphological and ecological convergence at the lower size limit for vertebrates highlighted by five new miniaturised microhylid frog species from three different Madagascan genera. Plos One 14: e0213314.

Schoch, R.R., P. Pogoda, A. Kupfer. 2019. The impact of metamorphosis on the cranial osteology of giant salamanders of the genus Dicamptodon. Acta Zoologica 2021: 88104.

Shubin, N.H. F.A. Jenkins Jr. 1995. An Early Jurassic jumping frog. Nature 377: 49-52.

Smith, B.P., M.J. Tyler, T. Kaneko, H.M. Garraffo, T.F. Spande, J.W. Daly. 2002. Evidence for biosynthesis of pseudophrynamine alkaloids by an Australian myobatrachid frog (Pseudophryne) and for sequestration of dietary pumiliotoxins. Journal of Natural Products 65: 439-447.

Streicher, J.W., S.P. Loader, A. Varela-Jaramillo, P. Montoya, R.O. de Sá. 2020. Analysis of ultraconserved elements supports African origins of narrow-mouthed frogs. Molecular Phylogenetics and Evolution 146: 106771.

Smirnov, S.V., A.B. Vasil'eva. 1995. Anuran dentition: development and evolution. Russian Journal of Herpetology 2: 120-128.

Thiery, A.P., T. Shono, D. Kurokawa, R. Britz, Z. Johanson, G.J. Fraser. 2017. Spatially restricted dental regeneration drives pufferfish beak development. Proceedings of the National Academy of Sciences 114: 4425-4434.

Tokita, M., W. Chaeychomsri, J. Siruntawineti. 2012. Developmental basis of toothlessness in turtles: insight into convergent evolution of vertebrate morphology. Evolution 67: 260273.

Trueb, L., C. Gans. 1983. Feeding specializations of the Mexican burrowing toad, Rhinophrinus dorsalis (Anura: Rhinophrynidae). Journal of Zoology 199: 189-208. 
Trueb, L., C.F. Ross, R.M.H. Smith. 2005. A new pipoid anuran from the Late Cretaceous of South Africa. Journal of Vertebrate Paleontology 25:533-547.

Tucker, A., P. Sharpe. 2004. The cutting-edge of mammalian development; how the embryo makes teeth. Nature Reviews Genetics 5: 499-508.

University of California, Berkeley. 2021. AmphibiaWeb: Information on amphibian biology and conservation. Available at amphibiaweb.org. Accessed January 15, 2021.

Vidal-Garcia, M., J.S. Keogh. 2017. Phylogenetic conservatism in skulls and evolutionary lability in limbs - morphological evolution across an ancient frog radiation is shaped by diet,

Vences, M., F. Glaw, W. Böhme. 1998. Evolutionary correlates of microphagy in alkaloidcontaining frogs (Amphibia: Anura). Zoologischer Anzeiger 236: 217-230.

Visser, J. 1981. Tooth counts for Dasypeltis (Serpentes: Dasypeltinae). The Journal of the Herpetological Association of Africa 25: 13-14.

Wake, M.H. 1976. The development and replacement of teeth in viviparous caecilians. Journal of Morphology 148: 33-63.

Wake, M.H., G.Z. Wurst. 1979. Tooth crown morphology in caecilians (Amphibia: Gymnophiona). Journal of Morphology 159: 331-341.

Wang, S., J. Stiegler, P. Wu, C.-M. Chuong, D. Hu, A. Balanoff, Y. Zhou, X. Xu. 2017. Heterochronic truncation of odontogenesis in theropod dinosaurs provides insight into the macroevolution of avian beaks. Proceedings of the National Academy of Sciences 114: 10930-10935.

Wiens, J.J. 2011. Re-evolution of lost mandibular teeth in frogs after more than 200 million years, and re-evaluating Dollo's Law. Evolution 65: 1283-1296.

Womack, M.C., R.C. Bell. 2020. Two-hundred million years of anuran body-size evolution in relation to geography, ecology and life history. Journal of Evolutionary Biology 33: 14171432.

Yang, T.-R., P.M. Sander. 2018. The origin of the bird's beak: new insights from dinosaur incubation periods. Biology Letters 14: 20180090.

Zweifel, R.G. 1971. Relationships and distribution of Genyophryne thomsoni, a microhylid frog of New Guinea. American Museum Novitates 2469: 1-13. 
bioRxiv preprint doi: https://doi org/10.1101/2021.02 04.429809; this version posted February 6, 2021. The copyright holder for this preprint

(which was not certified by peer review) is the author/funder, who has granted bioRxiv a license to display the preprint in perpetuity. It is made available under aCC-BY 4.0 International license.

\section{Supplemental Information}

768 Dataset S1: Spreadsheet of specimens examined (524 amphibian species) with associated

769 dentition data and MorphoSource DOIs.

770 Dataset S2: Compiled dietary data and references for 267 frog lineages.

771 Dataset S3: Measurement data (skull length, jaw length, SVL) for 423 frog species.

772 Datasets S1-3 and scripts for all analyses are available on GitHub at

773 https://github.com/dpaluh/edentulous frogs. 
bioRxiv preprint doi: https://doi.org/10.1101/2021.02 04 429809; this version posted February 6, 2021. The copyright holder for this preprint (which was not certified by peer review) is the author/funder, who has granted bioRxiv a license to display the preprint in perpetuity. It is made available under aCC-BY 4.0 International license.

Figure 1-figure supplement 1. Phylogeny of 524 amphibians depicting the evolution of dentition (toothed $=$ blue; edentulous $=$ red) with species tip labels.

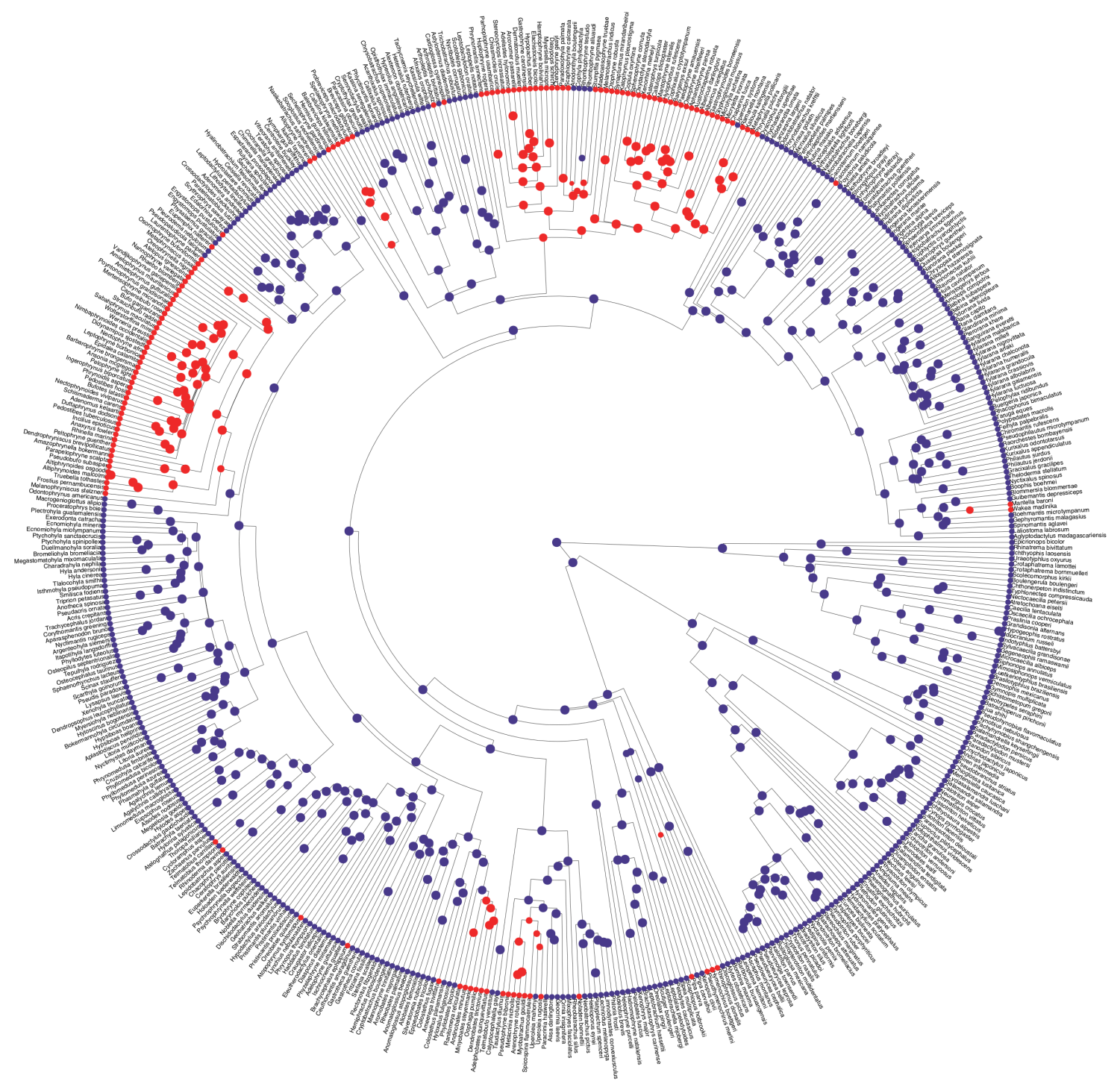


bioRxiv preprint doi: https://doi.org/10.1101/2021.02 04 429809: this version posted February 6, 2021. The copyright holder for this preprint (which was not certified by peer review) is the author/funder, who has granted bioRxiv a license to display the preprint in perpetuity. It is made available under aCC-BY 4.0 International license.

Figure 1-figure supplement 2. Phylogeny of 524 amphibians depicting the evolution of

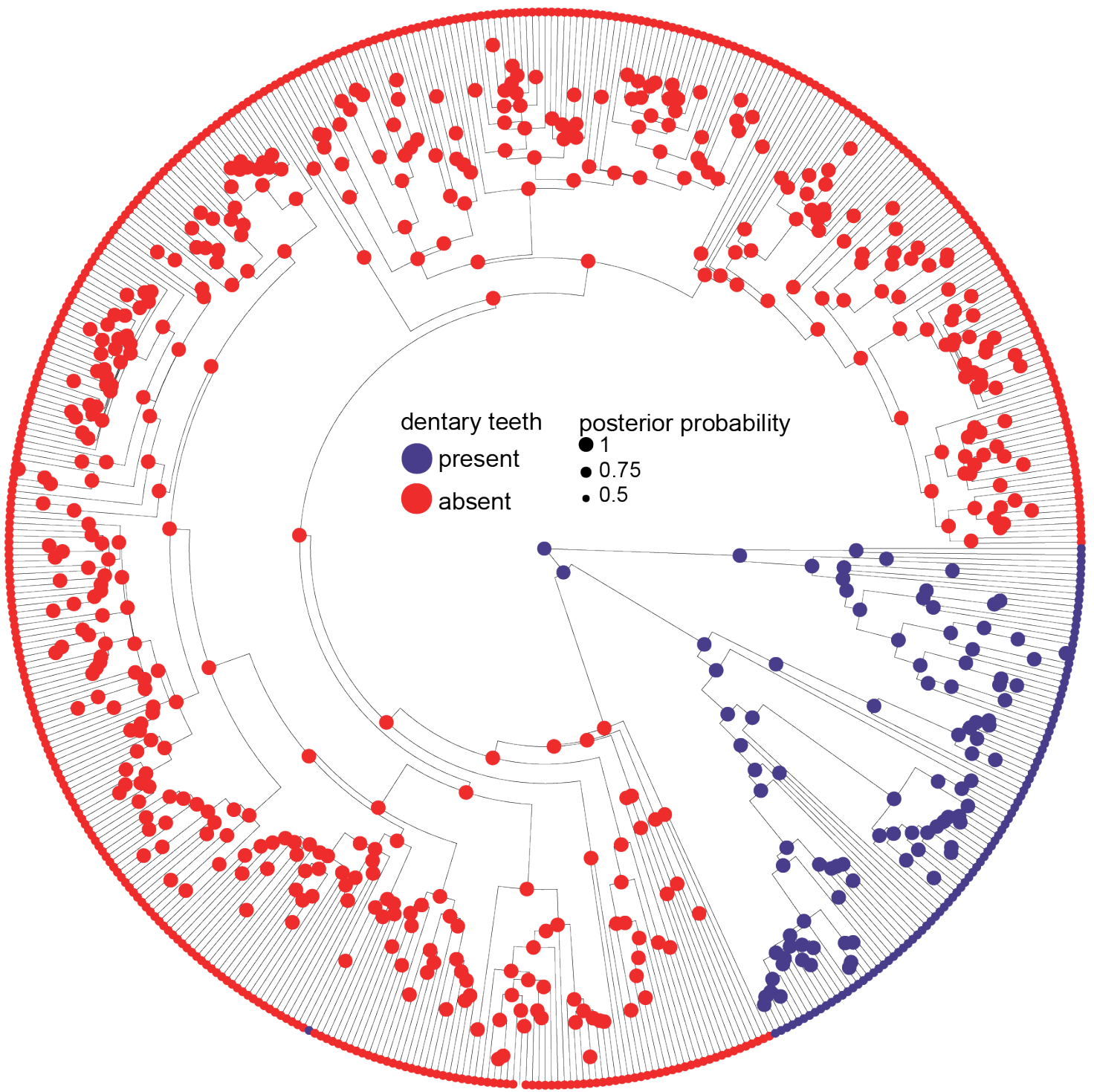


bioRxiv preprint doi: https://doi.org/10.1101/2021.02 04 429809. this version posted February 6, 2021. The copyright holder for this preprint (which was not certified by peer review) is the author/funder, who has granted bioRxiv a license to display the preprint in perpetuity. It is made available under aCC-BY 4.0 International license.

Figure 1-figure supplement 3. Phylogeny of 524 amphibians depicting the evolution of premaxillary teeth.

783

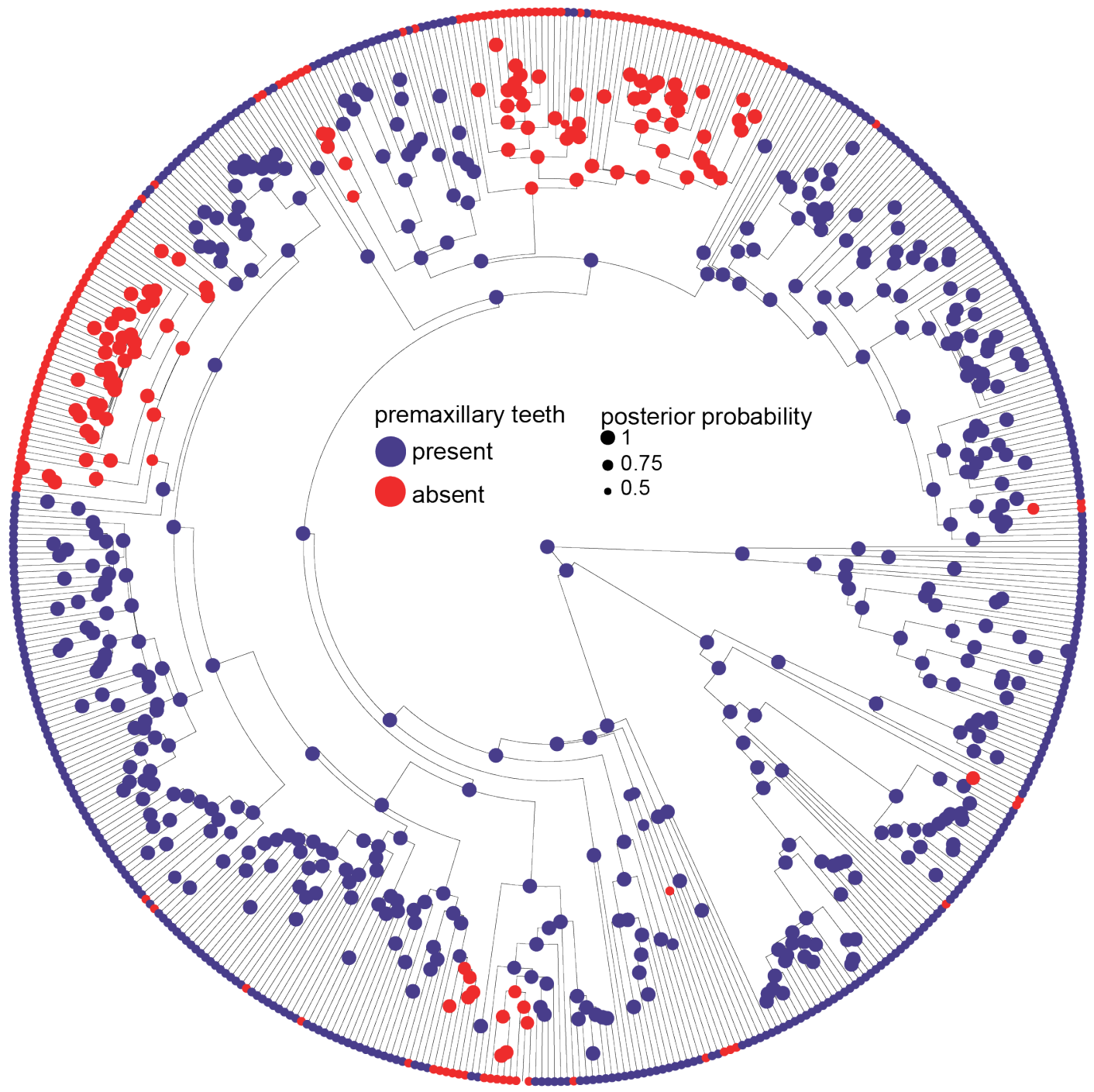


bioRxiv preprint doi: https://doi.org/10.1101/2021.02 04 429809. this version posted February 6, 2021. The copyright holder for this preprint (which was not certified by peer review) is the author/funder, who has granted bioRxiv a license to display the preprint in perpetuity. It is made available under aCC-BY 4.0 International license.

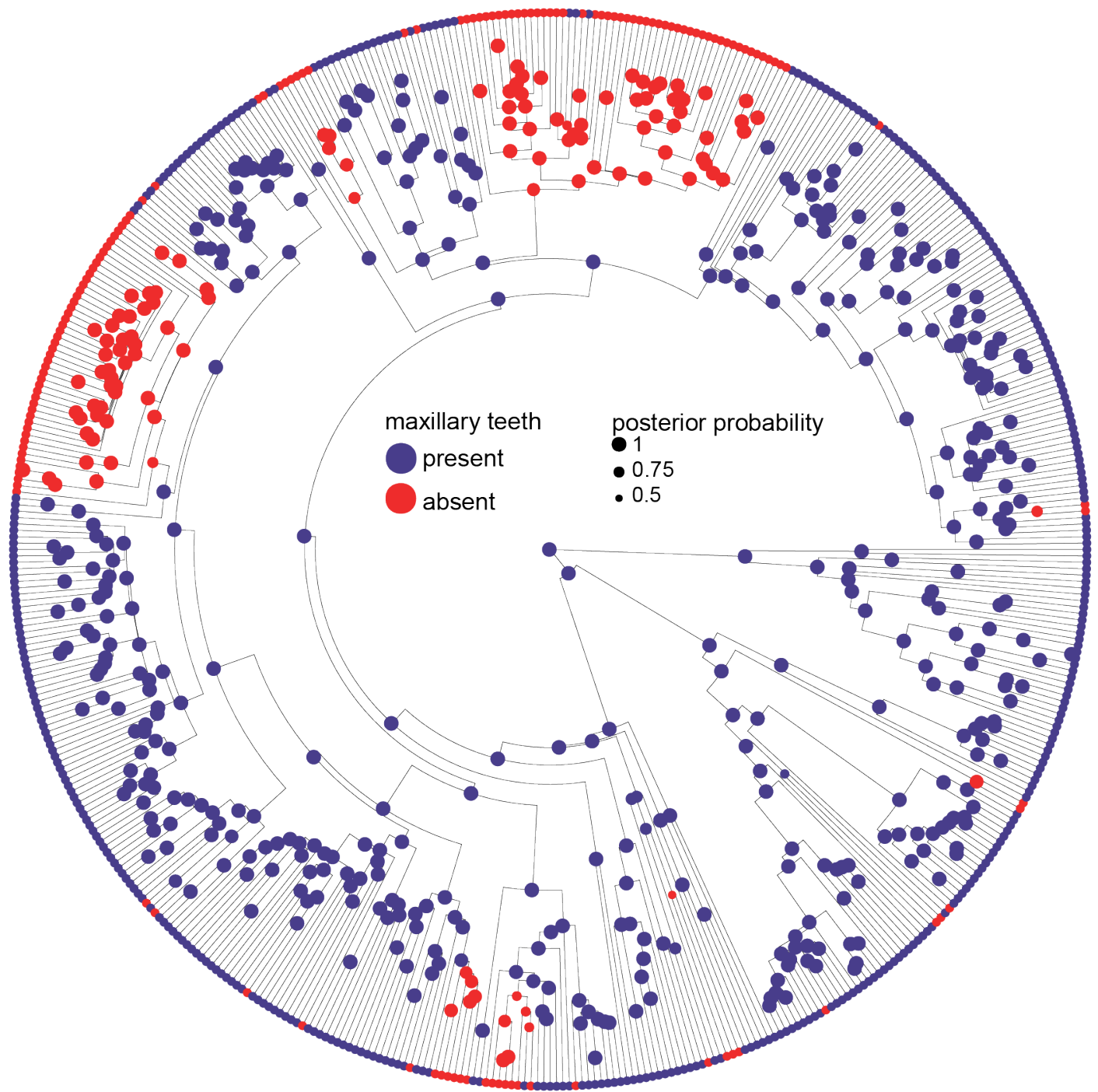


bioRxiv preprint doi: https://doi.org/10.1101/2021.02 04 429809. this version posted February 6, 2021. The copyright holder for this preprint (which was not certified by peer review) is the author/funder, who has granted bioRxiv a license to display the preprint in perpetuity. It is made available under aCC-BY 4.0 International license.

Figure 1 -figure supplement 5 . Phylogeny of 524 amphibians depicting the evolution of

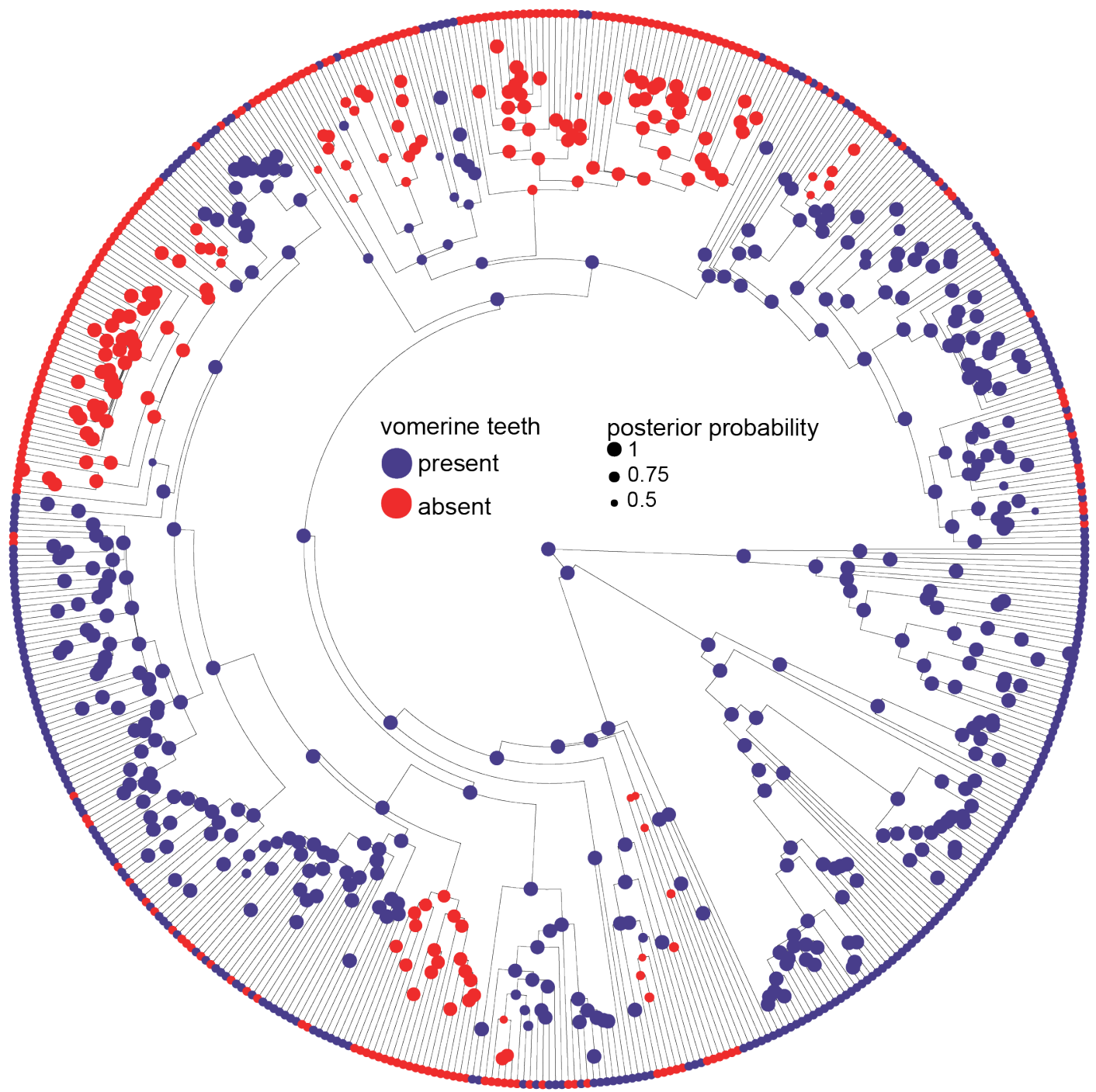


bioRxiv preprint doi: httos://doi org/101101/2021.02 04 429809. this version posted February 6.2021 The copvriaht holder for this preprint (which was not certified by peer review) is the author/funder, who has granted bioRxiv a license to display the preprint in perpetuity. It is made available under aCC-BY 4.0 International license.

792 Figure 2-figure supplement 1. Phylogeny of 267 frog species with a stochastic character map

793 of dentition and the distribution of diet states with species tip labels.

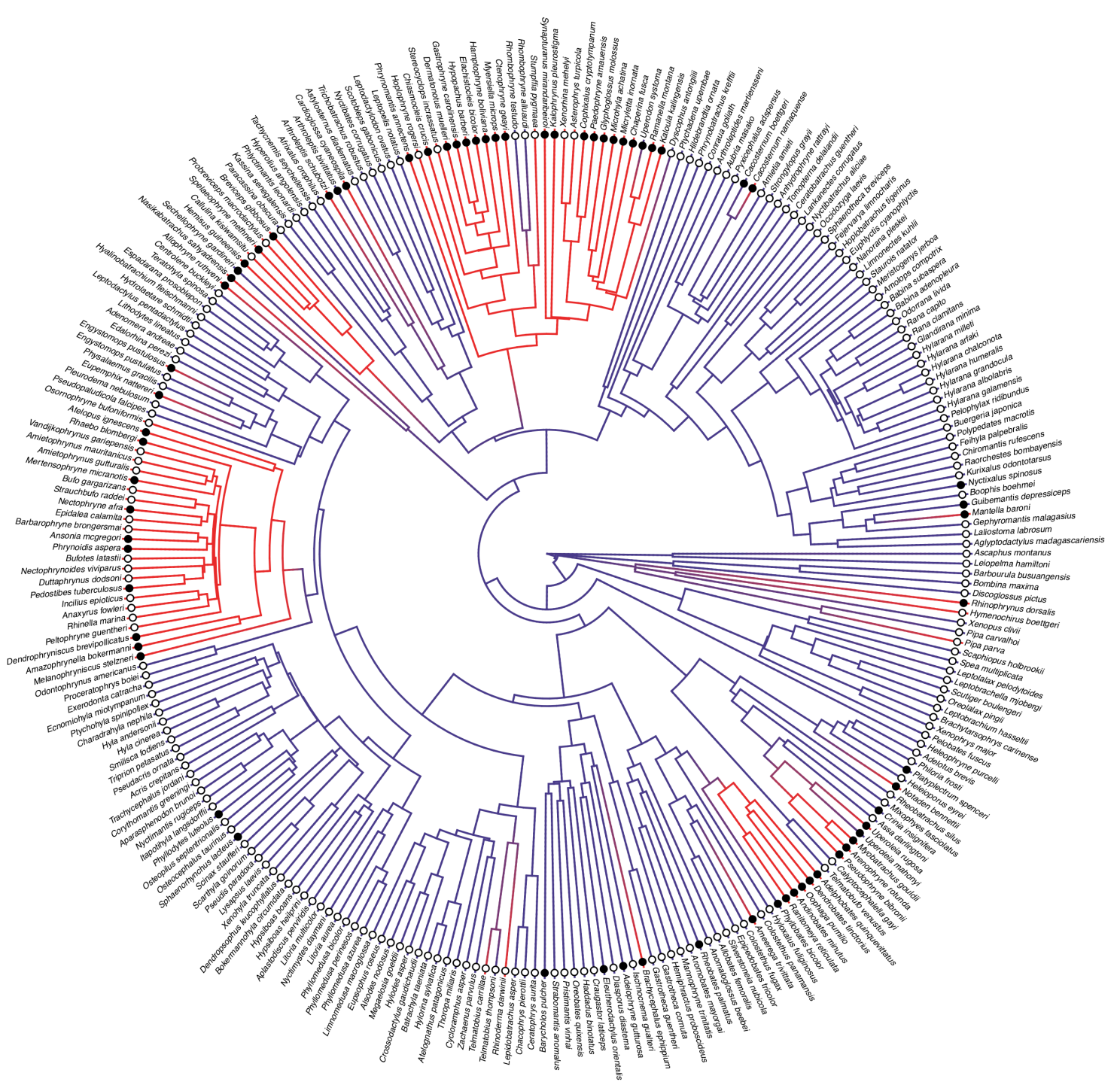

